\title{
Ocean-related global change alters lipid biomarker production in common marine phytoplankton
}

\author{
Rong Bi ${ }^{1,2,3}$, Stefanie M. H. Ismar-Rebitz ${ }^{3}$, Ulrich Sommer ${ }^{3}$, Hailong Zhang ${ }^{1,2}$, and Meixun Zhao ${ }^{1,2}$ \\ ${ }^{1}$ Frontiers Science Center for Deep Ocean Multispheres and Earth System, and Key Laboratory of Marine Chemistry Theory \\ and Technology, Ministry of Education, Ocean University of China, Qingdao 266100, China \\ ${ }^{2}$ Laboratory for Marine Ecology and Environmental Science, Qingdao National Laboratory for Marine Science and \\ Technology, Qingdao 266237, China \\ ${ }^{3}$ Marine Ecology, GEOMAR Helmholtz Centre for Ocean Research Kiel, Kiel, 24105, Germany
}

Correspondence: Meixun Zhao (maxzhao@ouc.edu.cn, maxzhao04@yahoo.com)

Received: 22 May 2020 - Discussion started: 8 June 2020

Revised: 19 October 2020 - Accepted: 28 October 2020 - Published: 14 December 2020

\begin{abstract}
Lipids, in their function as trophic markers in food webs and organic matter source indicators in the water column and sediments, provide a tool for reconstructing the complexity of global change effects on aquatic ecosystems. It remains unclear how ongoing changes in multiple environmental drivers affect the production of key lipid biomarkers in marine phytoplankton. Here, we tested the responses of sterols, alkenones and fatty acids (FAs) in the diatom Phaeodactylum tricornutum, the cryptophyte Rhodomonas sp. and the haptophyte Emiliania huxleyi under a full-factorial combination of three temperatures $\left(12,18\right.$ and $\left.24^{\circ} \mathrm{C}\right)$, three $\mathrm{N}: \mathrm{P}$ supply ratios (molar ratios 10:1, 24:1 and 63:1) and two $p \mathrm{CO}_{2}$ levels (560 and $2400 \mu \mathrm{atm}$ ) in semicontinuous culturing experiments. Overall, $\mathrm{N}$ and $\mathrm{P}$ deficiency had a stronger effect on per-cell contents of sterols, alkenones and FAs than warming and enhanced $p \mathrm{CO}_{2}$. Specifically, $\mathrm{P}$ deficiency caused an overall increase in biomarker production in most cases, while $\mathrm{N}$ deficiency, warming and high $p \mathrm{CO}_{2}$ caused nonsystematic changes. Under future ocean scenarios, we predict an overall decrease in carbon-normalized contents of sterols and polyunsaturated fatty acids (PUFAs) in E. huxleyi and $P$. tricornutum and a decrease in sterols but an increase in PUFAs in Rhodomonas sp. Variable contents of lipid biomarkers indicate a diverse carbon allocation between marine phytoplankton species in response to changing environments. Thus, it is necessary to consider the changes in key lipids and their consequences for food-web dynamics and biogeochemical cycles, when predicting the influence of global change on marine ecosystems.
\end{abstract}

\section{Introduction}

Ocean phytoplankton has profoundly responded to and driven natural climatic variability throughout Earth's history (Riding, 1992; Falkowski and Oliver, 2007; Falkowski, 2015). In the contemporary ocean, human-induced physical and chemical modifications are complex and concurrent, including warming, acidification, deoxygenation and changes in nutrient availability (Doney et al., 2012; Moore et al., 2013; DeVries et al., 2017). The ocean-related global change fundamentally affects marine ecosystems (HoeghGuldberg and Bruno, 2010). These include especially global phytoplankton biomass decreases (Boyce et al., 2010; Moore et al., 2018; Lotze et al., 2019) and plankton community changes (Richardson and Schoeman, 2004; Jonkers et al., 2019), which consequently alters food-web dynamics (Kortsch et al., 2015; du Pontavice et al., 2020) and biogeochemical cycles (Hofmann and Schellnhuber, 2009; Gruber, 2011; Doney et al., 2012). A major challenge is the lack of understanding of the complexity of biological impacts of global change, which has hindered the prediction of potential feedbacks between marine ecosystems and projected environmental changes. Some of the phytoplankton-produced biomolecules (biomarkers), functioning as indicators of nutritional food quality (Müller-Navarra, 2008) and tracers of organic matter sources (Volkman et al., 1998), have provided crucial insight into the trajectory of ecological responses to changing environment along food webs in the present-day ocean (Ruess and Müller-Navarra, 2019), as well as over geological time (Brocks et al., 2017). 
Lipids are amongst the most important and widely used biomarkers, because they have far-reaching biochemical and physiological roles in cells and are sensitive to environmental changes (Arts et al., 2009); they are also important because of their dominance in the geological record as fossil molecules to reveal life's signatures on Earth (Falkowski and Freeman, 2014). There are also growing applications of lipids as proxies for global climate and marine ecosystem change. Of all biomarkers, fatty acids (FAs), the basic constituents of most algal lipids, have received the most intense attention. Polyunsaturated fatty acids (PUFAs) are essential for many animals and have been applied as nutritional components to study trophic interactions (Brett and Müller-Navarra, 1997; Müller-Navarra et al., 2000; Dalsgaard et al., 2003; Kelly and Scheibling, 2012; Ruess and Müller-Navarra, 2019). The impact of environmental changes on phytoplankton FAs has been well studied, mostly with a focus on the effects of temperature and nutrient changes (reviewed by Guschina and Harwood, 2009; Galloway and Winder, 2015; Hixson and Arts, 2016), while the interplay between different environmental drivers has been recently tested (Bermúdez et al., 2015; Bi et al., 2017, 2018). However, determining how phytoplankton lipids respond to global change still faces substantial challenges, partly because data on other important lipid classes such as sterols and alkenones are scarce. Understanding the impact of environmental change on these lipid classes is critical to achieve a better application of lipid biomarkers to contemporary issues and to the past record of marine ecosystems.

Sterols are tetracyclic triterpenoids present in all eukaryotes (Volkman, 2003, 2016). Sterols function primarily as structural components of plasma membranes but also play key roles in cellular defense against toxic compounds and signal transduction, and they serve as precursors to several important compounds (e.g., steroid hormones in animals) involved in cellular and developmental processes (Hartmann, 1998; Guschina and Harwood, 2009; Fabris et al., 2012). In ecology, sterols have been used as indicators of dietary nutritional quality, because some invertebrates are incapable of synthesizing sterols de novo and thus must obtain sterols from their diets (reviewed by Martin-Creuzburg and von Elert, 2009b). In geochemistry, sterols such as 24-methylcholesta-5,22E-dien-3 $\beta$-ol (brassicasterol / epi-brassicasterol) and $4 \alpha, 23,24$-trimethylcholest$22 \mathrm{E}$-en-3 $\beta$-ol (dinosterol) have been applied to reconstruct diatom and dinoflagellate production and community structure on historical and geological timescales (Volkman, 1986; Schubert et al., 1998; Zimmerman and Canuel, 2002; Xing et al., 2016). Given the multiple biochemical roles and source specificity of sterols, their composition and biosynthetic pathways in phytoplankton have been identified in different phyla (Fabris et al., 2014; Villanueva et al., 2014; Volkman, 2016). It has been observed that sterol contents (per carbon or dry weight or percentage of total lipids) in phytoplankton vary with environmental conditions. Véron et al. (1996) found a dramatic decrease in total sterol contents (per dry weight) in Phaeodactylum tricornutum as temperature increased. In contrast, a significant increase in carbonnormalized sterol contents with increasing temperature was found in other algal species (Piepho et al., 2012; Ding et al., 2019). Enhanced $p \mathrm{CO}_{2}$ caused an increase in the percentage of sterols (\% of total lipids) in Dunaliella viridis (Gordillo et al., 1998) but no clear change in per-cell contents of sterols in Emiliania huxleyi (Riebesell et al., 2000). Although significant interactions between two environmental factors have been observed on carbon-normalized or per-cell sterol contents in certain phytoplankton species (Piepho et al., 2010, 2012; Ding et al., 2019), the impacts of multiple environmental drivers on phytoplankton sterol contents have not been thoroughly investigated.

Long-chain alkenones are major lipids produced only by certain species of haptophytes, e.g., oceanic species $E$. huxleyi and Gephyrocapsa oceanica (Volkman et al., 1980c; Conte et al., 1995) and coastal species Isochrysis galbana (reviewed by Conte et al., 1994). Alkenones in E. huxleyi are believed to be used for energy storage (Epstein et al., 2001; Eltgroth et al., 2005), while little is known about the entire biosynthetic pathway of alkenones and their evolutionary and ecological functions (Rontani et al., 2006; Kitamura et al., 2018). Alkenones may have fitness and trophic benefit for their producers, because these unusual lipids are not only more photostable than other neutral lipids such as triacylglycerols but are also resistant to digestion, perhaps making alkenone producers less suitable for grazers (Eltgroth et al., 2005). Moreover, alkenones are well preserved in sediments over millions of years and thus their unsaturation ratios (e.g., the $U_{37}^{K^{\prime}}$ index $\left(=\mathrm{C}_{37: 2} /\left(\mathrm{C}_{37: 2}+\mathrm{C}_{37: 3}\right)\right)$; Brassell et al., 1986; Prahl and Wakeham, 1987) are widely applied for reconstructing sea surface temperatures (Rosell-Melé and Prahl, 2013; Herbert et al., 2016). A long-standing issue for the use of alkenones to infer paleo-ocean surface temperature is how the production of these compounds is influenced by other environmental factors such as nutrients. Thus, culture studies have been conducted to test alkenone contents (mostly per-cell contents) in several species of haptophytes such as E. huxleyi under different growth phases (Wolhowe et al., 2009; Pan and Sun, 2011; Wolhowe et al., 2015), salinity (Sachs et al., 2016), temperature (Ding et al., 2019) and nutrient concentrations (Rokitta et al., 2014; Wördenweber et al., 2018). Conflicting results have been observed in different studies, e.g., independence of $\mathrm{C}_{37}-\mathrm{C}_{39}$ alkenone contents on temperature (Prahl et al., 1988) versus significant responses of $\mathrm{C}_{37}$ alkenone contents to temperature changes in E. huxleyi (Ding et al., 2019). More empirical evidence appears necessary to determine how the total contents and the ratios of specific alkenone isomers respond to multiple environmental drivers, which would allow us to better understand their roles in ecology and biogeochemistry.

Here, we present data from semicontinuous culture experiments to tackle the question of how important lipid biomark- 
ers (FAs, sterols and alkenones) respond to the changes in multiple environmental drivers (temperature, $\mathrm{N}$ : $\mathrm{P}$ supply ratios and $p \mathrm{CO}_{2}$ ) in three phytoplankton species (the diatom $P$. tricornutum, the cryptophyte Rhodomonas sp. and the haptophyte E. huxleyi). Specifically, we analyze the changes of particulate organic carbon (POC)-normalized (carbonnormalized hereafter) and per-cell contents of major sterols and alkenones in the three species, and we compare these responses with those of published FA data from the same experiments. Our aims are to determine (i) how sterols and alkenones respond to the changes of multiple environmental drivers and (ii) how the responses of sterols, alkenones and FAs differ between each other. The goal of this study is to generate a better understanding of the impact of oceanrelated global change on lipid biomarker productions in marine phytoplankton, which will help to quantitatively apply lipid biomarkers as proxies for ecosystem change, and to finally scale up from specific physiological roles of lipids to their effects on energy flow in food webs in the changing ocean.

\section{Materials and methods}

\subsection{Experimental design}

The three phytoplankton species used in the experiments were the diatom P. tricornutum (SAG, 1090-1b; isolated from Plymouth, UK; De Martino et al., 2007), the cryptophyte Rhodomonas sp. (isolated from the Kiel Bight, Baltic Sea, and identified by the working group at GEOMAR; maintained and still available from GEOMAR for laboratory culture) and the haptophyte E. huxleyi (internal culture collection reference code: A8; isolated from waters off Terceira Island, the Azores). P. tricornutum and Rhodomonas sp. are model species widely used in studies of diatom genomes, cryptophyte photosynthesis and planktonic trophic dynamics (Bi et al., 2017), and E. huxleyi is one of the major calcifying organisms in the pelagic ocean (Winter et al., 2014). The algal cultures were non-axenic. Because the biomass of bacteria was very low, the bacterial influence on the chemical composition of phytoplankton was negligible. Over the course of the experiments, the cultures of all species were exposed to a salinity of $37 \mathrm{psu}$ and a light intensity of $100 \mu \mathrm{mol}$ photons $\mathrm{m}^{-2} \mathrm{~s}^{-1}$ following a light / dark cycle of $16 / 8 \mathrm{~h}$ in temperature-controlled rooms of 12,18 and $24^{\circ} \mathrm{C}$. The culture medium was prepared according to the modified Provasoli's medium (Provasoli, 1963; Ismar et al., 2008), with enrichment nutrient solutions added to sterile, filtered $\left(0.2 \mu \mathrm{m}\right.$ pore size, Sartobran ${ }^{\circledR}$ P 300; Sartorius, Göttingen, Germany) North Sea water. Sodium nitrate and potassium dihydrogen phosphate were added to achieve the molar ratios of $10: 1\left(35.2 \mu \mathrm{mol} \mathrm{L}^{-1} \mathrm{~N}\right.$ and $3.6 \mu \mathrm{mol} \mathrm{L}-1 \mathrm{P}), 24: 1\left(88 \mu \mathrm{mol} \mathrm{L}-1 \mathrm{~N}^{-1} 3.6 \mu \mathrm{mol} \mathrm{L}^{-1} \mathrm{P}\right)$ and $63: 1\left(88 \mu \mathrm{mol} \mathrm{L}^{-1} \mathrm{~N}\right.$ and $\left.1.4 \mu \mathrm{mol} \mathrm{L}{ }^{-1} \mathrm{P}\right)$. Sodium sili- cate pentahydrate was also added to diatom cultures at a concentration of $88 \mu \mathrm{mol} \mathrm{L}^{-1}$. Initial $p \mathrm{CO}_{2}$ was manipulated by bubbling with $\mathrm{CO}_{2}$-enriched air (560 and $2400 \mu \mathrm{atm}$ ). Subsequently, the culture medium was transferred into sealed cell culture flasks with a $920 \mathrm{~mL}$ culture volume. Each treatment was replicated three times. All culture flasks were carefully agitated twice per day at a set time to minimize sedimentation.

At the onset of the experiments, each species was grown in batch cultures across a fully factorial combination of three temperatures $\left(12,18\right.$ and $\left.24^{\circ} \mathrm{C}\right)$, three $\mathrm{N}: \mathrm{P}$ supply ratios (molar ratios 10:1, 24:1 and 63:1) and two $p \mathrm{CO}_{2}$ levels (560 and $2400 \mu \mathrm{atm}$ ) (Fig. S1 in the Supplement). The chosen levels of temperature, $\mathrm{N}$ : $\mathrm{P}$ supply ratio and $p \mathrm{CO}_{2}$ cover the ranges of typical changes of the three factors in natural environments, and they are in general agreements with projections. The temperature regimes broadly conform to sea surface temperatures in the source regions for the three taxa studied: Plymouth, UK, for P. tricornutum $\left(\sim 9-17^{\circ} \mathrm{C}\right)$ (Highfield et al., 2010); the Kiel Bight for Rhodomonas sp. ( $~ 3-18^{\circ} \mathrm{C}$ ) (Hiebenthal et al., 2013); and the Azores for $E$. huxleyi $\left(16-22^{\circ} \mathrm{C}\right.$; http://dive.visitazores.com/en/when-dive, last access: 17 September 2019). The $6{ }^{\circ} \mathrm{C}$ elevation also mimics the largest projected warming under climate change scenarios (Sommer and Lengfellner, 2008). N : P molar ratio of $24: 1$ was selected as the balanced ratio under which phytoplankton cultures are typically maintained (Guillard, 1975). Surface ocean inorganic N and P concentrations are highly depleted throughout much of the low-latitude oceans (Moore et al., 2013). Nutrient availability in the future will be altered by increasing external nutrient inputs especially in coastal oceans, changes in surface ocean chemistry driven by anthropogenic increases in atmospheric $\mathrm{CO}_{2}$ and changes in ocean circulation (Moore et al., 2013). Therefore, inorganic $\mathrm{N}$ : $\mathrm{P}$ ratios show a strong spatial variation in the oceans, e.g., a low ratio of $6: 1 \mathrm{~mol} \mathrm{~mol}^{-1}$ in the center of the South Pacific Gyre versus a global scenario of an increase driven by the high $\mathrm{N}: \mathrm{P}$ atmospheric deposition of $\sim 370: 1 \mathrm{~mol} \mathrm{~mol}^{-1}$ (Bonnet et al., 2008; Peñuelas et al., 2012). N : P ratios of $10: 1$ and $63: 1$ selected in this study cover large-scale spatial patterns of nutrient status, and thus our prediction of lipid biomarker production changes is based on both future open-ocean and coastal conditions. Partial $\mathrm{CO}_{2}$ pressure of $560 \mu \mathrm{atm}$ is double the preindustrial value and is a standard level for determining climate model sensitivity to $p \mathrm{CO}_{2}$ forcing (e.g., IPCC, 2014). The value of $2400 \mu \mathrm{atm}$ is at the mid-range of the projected values (1371-2900 $\mu \mathrm{atm})$ by 2150 (RCP8.5 scenario; IPCC, 2014). Also, a high $p \mathrm{CO}_{2}$ has been observed in the areas where one of the studied algae was isolated, e.g., 375-2309 $\mu \mathrm{atm}$ in the Kiel Bight (Thomsen et al., 2010).

The observed maximal growth rate $\left(\mu_{\max }, \mathrm{d}^{-1}\right)$ was calculated from the changes of cell numbers within the exponential growth phase in batch cultures (Bi et al., 2012). Once the early stationary phase was reached, semicontinuous cul- 
tures were started with the algae from batch cultures, and the gross growth rate $\left(\mu, \mathrm{d}^{-1}\right)$ was set as $20 \%$ of $\mu_{\max }$. We calculated the volume of the daily renewal incubation water by multiplying daily renewal rate $\left(D, \mathrm{~d}^{-1} ; D=1-e^{-\mu \cdot t}\right.$, where $t$ is renewal interval; here $t=1 \mathrm{~d}$ ) with the incubation volume of $920 \mathrm{~mL}$. According to the gross growth rate of $20 \%$ of $\mu_{\max }$, the renewal volumes were about $10 \%$ of the total culture volume $(100-200 \mathrm{~mL}$ out of $920 \mathrm{~mL})$, and renewal interval was $1 \mathrm{~d}$. Steady state was reached at about $10 \mathrm{~d}$ with slight differences between the individual cultures. Renewal of the cultures was carried out at the same hour every day using fresh, filtered seawater pre-acclimated to target $p \mathrm{CO}_{2}$ - and $\mathrm{CO}_{2}$-enriched water. The difference between the gross growth rate and the loss rate, i.e., the net growth rate $\left(r\left(\mathrm{~d}^{-1}\right) ; r=\mu-D\right)$, was used to assess the steady state, at which $r$ was zero and $\mu$ was equivalent to $D$.

\subsection{Sampling and measurements}

At steady state in semicontinuous cultures, samples were collected for the measurements of cell density, dissolved inorganic carbon (DIC), total alkalinity, pH, POC, FAs, sterols and alkenones. Cell density was measured daily in batch and semicontinuous cultures using an improved Neubauer hemacytometer (Glaswarenfabrik Karl Hecht GmbH, Rhön Mountains, Germany) under a microscope (Hund, Wetzlar, Germany). Also, $\mathrm{pH}$ measurements were carried out daily in semicontinuous cultures, and the electrode was calibrated using standard $\mathrm{pH}$ buffers ( $\mathrm{pH} 4$ and $\mathrm{pH}$ 7; WTW, Weilheim, Germany).

DIC samples were taken on sampling days with $10 \mathrm{~mL}$ glass vials (Resteck, Germany) filled using a peristaltic pump and an intake tube containing a single-use syringe filter ( $0.2 \mu \mathrm{m}$, Minisart RC25; Sartorius, Göttingen, Germany). Vials were immediately sealed and stored in the dark at $4{ }^{\circ} \mathrm{C}$. DIC was measured according to Hansen et al. (2013) using a gas chromatographic system (8610C; SRI-Instruments, California, USA). For total alkalinity analysis, samples were filtered (GF/F filters; Whatman GmbH, Dassel, Germany) and analyzed with the Tirino plus 848 (Metrohm, Filderstadt, Germany). The remaining carbonate parameter $p \mathrm{CO}_{2}$ was calculated from DIC and total alkalinity using CO2SYS (Pierrot et al., 2006) and the constants of Hansson (1973) and Mehrbach et al. (1973) that were refitted by Dickson and Millero (1987) (Table S1 in the Supplement; Bi et al., 2017, 2018). DIC and $\mathrm{pH}$ did not differ substantially between different temperature and $\mathrm{N}: \mathrm{P}$ ratio treatments in our study (Table $\mathrm{S} 1$ ).

POC and FA samples $(15-50 \mathrm{~mL})$ were taken on precombusted and prewashed $(5 \%-10 \% \mathrm{HCl}) \mathrm{GF} / \mathrm{F}$ filters (Whatman $\mathrm{GmbH}$, Dassel, Germany). After filtration, filters for POC analysis were immediately dried at $60^{\circ} \mathrm{C}$ and stored in a desiccator, and those for FA measurements were stored at $-80^{\circ} \mathrm{C}$. For POC analysis in E. huxleyi, particulate inorganic carbon was removed by exposing filters to fuming hydrochloric acid for $12 \mathrm{~h}$. POC was determined using an elemental analyzer (Thermo Flash 2000; Thermo Fisher Scientific, Schwerte, Germany) after Sharp (1974). FAs were measured as FA methyl esters (FAMEs) using a gas chromatograph (Trace GC Ultra; Thermo Fisher Scientific, Schwerte, Germany). Analytical procedure of FAs was modified after Christie (1989). Briefly, FAs were extracted with a solvent mixture of chloroform / dichloromethane / methanol (1:1:1, volume ratios). The FAME 19:0 was added as an internal standard and $21: 0$ as a esterification control. The extracted FAMEs were dissolved in $100 \mu \mathrm{L} n$-hexane for analysis. Sample aliquots $(1 \mu \mathrm{L})$ were injected onto the gas chromatograph (GC) with hydrogen as the carrier gas. Individual FAs were identified with reference to the standards (Supelco 37 component FAME mixture and Supelco Menhaden fish oil), and the peaks were integrated using Chromcard software (Thermo Fisher Scientific, Schwerte, Germany), which included saturated, monounsaturated and polyunsaturated FAs (Bi et al., 2017, 2018).

Samples for sterol and alkenone analysis were filtered (GF/F filters; Whatman GmbH, Dassel, Germany) and measured according to the procedure of Zhao et al. (2006). The filtration volume of sterol and alkenone samples was 100$200 \mathrm{~mL}$, while only $10 \%$ of the extractions were used for GC quantification and the rest was stored for later use. Lipids were extracted ultrasonically eight times from the freezedried filter samples utilizing dichloromethane and methanol ( $3: 1$, volume ratios) as extraction solvent, with $\mathrm{C}_{19} n$ alkanol added for quantification. After hydrolysis with $6 \%$ potassium hydroxide in dichloromethane, the lipids were separated into a polar fraction and a nonpolar fraction using silica gel chromatography. The polar lipid fractions containing sterols from the extracts of all the three species, as well as $\mathrm{C}_{37}-\mathrm{C}_{39}$ alkenones from the E. huxleyi extracts, were eluted with $22 \mathrm{~mL}$ dichloromethane and methanol $(95: 5$, volume ratios). Subsequently, the polar lipid fractions were silylated with $80 \mu \mathrm{L} \mathrm{N,O-bis(trimethylsilyl)-trifluoroacetamide}$ at $70^{\circ} \mathrm{C}$ for $1 \mathrm{~h}$. The sterol and alkenone fractions were analyzed and quantified using an Agilent 7890A GC with flame ionization detection (50 m HP-1 capillary column, $0.32 \mathrm{~mm}$ i.d., $0.17 \mu \mathrm{m}$ film thickness) by comparing analyte peak area to known amount of the internal standard $\mathrm{C}_{19}$ $n$-alkanol. The oven temperature held initially at $80^{\circ} \mathrm{C}$ for $1 \mathrm{~min}$; it was then increased to $200^{\circ} \mathrm{C}$ at $25^{\circ} \mathrm{C} \mathrm{min}^{-1}$, to $250^{\circ} \mathrm{C}$ at $4^{\circ} \mathrm{C} \mathrm{min}^{-1}$, to $300^{\circ} \mathrm{C}$ at $1.7^{\circ} \mathrm{C} \mathrm{min}^{-1}$ (holding for $12 \mathrm{~min}$ ), and finally to $315^{\circ} \mathrm{C}$ at $5^{\circ} \mathrm{C} \mathrm{min}^{-1}$ with an $8 \mathrm{~min}$ isothermal period.

The identification of brassicasterol / epi-brassicasterol, the major sterol in all three species, was conducted with reference to laboratory standards. In marine systems, the most likely epimer for 24-methylcholesta-5,22E-dien-3 $\beta$-ol is epi-brassicasterol $(24 \alpha)$ synthesized by diatoms (Gladu et al., 1990, 1991), cryptophytes (Goad et al., 1983) and haptophytes (Maxwell et al., 1980). In contrast, 24 $\beta$ methylcholesta-5,22E-dien-3 $\beta$-ol (brassicasterol) has been 
also found, e.g., in a strain of the haptophyte Isochrysis (Gladu et al., 1990). As the stereochemistry at C-24 could not be determined in our study, we use the trivial name brassicasterol / epi-brassicasterol for 24-methylcholesta-5,22E-dien$3 \beta$-ol.

Alkenones were identified using an Agilent GC 7890B (30 m HP-5MS column, $0.25 \mathrm{~mm}$ i.d., $0.25 \mu \mathrm{m}$ film thickness) connected to an Agilent MSD 5977B mass selective detector $(70 \mathrm{eV}$ constant ionization potential, ion source temperature $230^{\circ} \mathrm{C}$ ). The temperature program started with a $1 \mathrm{~min}$ hold time at $80^{\circ} \mathrm{C}$ and then increased to $200^{\circ} \mathrm{C}$ at $25^{\circ} \mathrm{C} \mathrm{min}^{-1}$, followed by a $4^{\circ} \mathrm{min}^{-1} \mathrm{ramp}$ to $250^{\circ} \mathrm{C}$ and a $1.8^{\circ} \mathrm{C} \mathrm{min}^{-1}$ ramp to $300^{\circ} \mathrm{C}$ (holding for $10 \mathrm{~min}$ ); finally the temperature increased to $315^{\circ} \mathrm{C}$ at $5^{\circ} \mathrm{C} \mathrm{min}^{-1}$ (holding for $5 \mathrm{~min}$ ). Alkenone identifications were performed by comparing sample mass spectra generated by GC-MS to previously published EI (electron ionization) mass spectra, based on the molecular ion and prominent ions of each alkenone component (de Leeuw et al., 1980; Volkman et al., 1980c; Lopez and Grimalt, 2006). Note that the molecular ions for $\mathrm{C}_{39}: 3$ ethyl ketone ( $\left.\mathrm{C}_{39: 3} \mathrm{Et}\right)\left(\right.$ at $m / z$ 556) and $\mathrm{C}_{39}: 2$ ethyl ketone $\left(\mathrm{C}_{39: 2} \mathrm{Et}\right)($ at $\mathrm{m} / \mathrm{z}, 558)$ were below detection; only prominent ion fragments were detected. In addition, the comparisons of the GC retention times of alkenone molecules between our study and previous work (Volkman et al., 1980c) indicated the presence of $\mathrm{C}_{39: 3}$ Et and $\mathrm{C}_{39: 2} \mathrm{Et}$.

\subsection{Statistics}

Generalized linear mixed models (GLMMs; Bolker et al., 2009) were used to test the effects of temperature, $\mathrm{N}: \mathrm{P}$ supply ratios and $p \mathrm{CO}_{2}$ on carbon-normalized and per-cell contents of brassicasterol / epi-brassicasterol and $\mathrm{C}_{37}-\mathrm{C}_{39}$ total alkenones (as $\mu \mathrm{g} \mathrm{mg} \mathrm{C}^{-1}$ and $\mathrm{pg}$ cell $^{-1}$ ); per-cell contents of $\mathrm{C}_{37}$ alkenones, $\mathrm{C}_{38}$ alkenones, $\mathrm{C}_{38}$ ethyl ketones $\left(\mathrm{C}_{38} \mathrm{Et}\right)$, and $\mathrm{C}_{38}$ methyl ketones $\left(\mathrm{C}_{38} \mathrm{Me}\right) ; \mathrm{C}_{37} / \mathrm{C}_{38}$ alkenone ratios; and $\mathrm{C}_{38} \mathrm{Et} / \mathrm{C}_{38} \mathrm{Me}$ ratios $\left(\mathrm{C}_{38} \mathrm{Et} / \mathrm{Me}\right)$, with temperature, $\mathrm{N}$ : $\mathrm{P}$ supply ratios and $p \mathrm{CO}_{2}$ as fixed effects. Target distributions were tested before GLMMs were taken. Subsequently, appropriate link functions were chosen, e.g., identity link function for any distribution except for multinomial and logit link function for the binomial or multinomial distribution. To find the model that best predicted targets, we tested models containing first-order effects and second- and third-order interactions of temperature, $\mathrm{N}: \mathrm{P}$ supply ratios and $p \mathrm{CO}_{2}$. The Akaike Information Criterion corrected (AICc) was used to select the best model for each response variable, with a lower AICc value representing a better fit of the model. When the changes of AICc values were 10 units or more, it was considered a reasonable improvement in the fitting of GLMMs (Bolker et al., 2009). In case AICc values were comparable ( $<10$ units difference), the simpler model was chosen. Based on the differences in AICc values, models containing only first-order effects of temperature, $\mathrm{N}$ : $\mathrm{P}$ supply ratios and $p \mathrm{CO}_{2}$ were chosen as the best models for all response variables (bold letters in Table S2), while those containing second- or third-order interactions were not selected.

Principal component analysis (PCA) was conducted to visualize the responses of carbon-normalized contents of brassicasterol / epi-brassicasterol and total fatty acids (TFAs) in the three species and total alkenones in E. huxleyi to the changes of temperature, $\mathrm{N}: \mathrm{P}$ supply ratios and $p \mathrm{CO}_{2}$. Data for TFAs were from previous studies (Bi et al., 2017, 2018).

GLMMs were performed using SPSS 19.0 (IBM Corporation, New York, USA). PCA was conducted using R packages factoextra (Kassambara and Mundt, 2017) and FactoMineR (Le et al., 2008) in R version 3.5.1 (R Development Core Team, R Foundation for Statistical Computing, Vienna, Austria). All statistical tests were conducted at a significance threshold of $p=0.05$.

\section{Results}

\subsection{Sterol and alkenone composition}

Brassicasterol / epi-brassicasterol was the major sterol observed in all the three species, while alkenones were only detected in E. huxleyi. The alkenones in E. huxleyi consisted of four pairs of homologues, i.e., $\mathrm{C}_{37}$ methyl ketones $\left(\mathrm{C}_{37}\right.$ Me including $\mathrm{C}_{37: 4} \mathrm{Me}, \mathrm{C}_{37: 3} \mathrm{Me}$ and $\mathrm{C}_{37: 2 \mathrm{Me}}, \mathrm{C}_{38} \mathrm{Me}$ $\left(\mathrm{C}_{38: 3} \mathrm{Me}\right.$ and $\left.\mathrm{C}_{38: 2} \mathrm{Me}\right), \mathrm{C}_{38}$ ethyl $\left(\mathrm{C}_{38: 3} \mathrm{Et}\right.$ and $\mathrm{C}_{38: 2}$ Et) and $\mathrm{C}_{39}$ Et ketones $\left(\mathrm{C}_{39}\right.$ Et including $\mathrm{C}_{39: 3}$ Et and $\mathrm{C}_{39: 2}$ Et). $\mathrm{C}_{37}$ Me compounds were the most abundant, followed by $\mathrm{C}_{38} \mathrm{Et}, \mathrm{C}_{38} \mathrm{Me}$ and $\mathrm{C}_{39} \mathrm{Et}$.

\subsection{Responses of brassicasterol / epi-brassicasterol to environmental changes}

GLMM results showed that per-cell contents of brassicasterol / epi-brassicasterol responded significantly to changes in $\mathrm{N}: \mathrm{P}$ supply ratios in the three species (bold letters in Table 1). Moreover, per-cell contents of brassicasterol / epibrassicasterol in $P$. tricornutum also showed significant responses to temperature changes, while nonsignificant effects of $p \mathrm{CO}_{2}$ were observed in all species. Specifically, higher per-cell contents of brassicasterol / epi-brassicasterol were observed at higher temperatures and higher $\mathrm{N}: \mathrm{P}$ supply ratios in P. tricornutum (Fig. 1a; Table S3), under the lowest and highest $\mathrm{N}: \mathrm{P}$ supply ratios in Rhodomonas $\mathrm{sp}$. (Fig. 1c) and under higher $\mathrm{N}$ : $\mathrm{P}$ supply ratios in E. huxleyi (Fig. 1e).

Carbon-normalized contents of brassicasterol / epibrassicasterol responded significantly to $p \mathrm{CO}_{2}$ in Rhodomonas $\mathrm{sp}$. and to temperature and $\mathrm{N}: \mathrm{P}$ supply ratios in E. huxleyi (bold letters in Table 1) but with nonsignificant responses in $P$. tricornutum. Carbon-normalized contents of brassicasterol / epi-brassicasterol in Rhodomonas sp. decreased as $p \mathrm{CO}_{2}$ increased (Fig. 1d), while those in $E$. huxleyi were generally higher at higher temperatures and under the balanced $\mathrm{N}: \mathrm{P}$ supply ratio $\left(\mathrm{N}: \mathrm{P}=24: 1 \mathrm{~mol} \mathrm{~mol}^{-1}\right.$; Fig. 1e). 
Table 1. Results of the selected GLMMs testing for the effects of temperature, $\mathrm{N}: \mathrm{P}$ supply ratios and $p \mathrm{CO}_{2}$ on carbon-normalized and per-cell contents of brassicasterol / epi-brassicasterol (brassi. / epi-brassi. / POC and brassi. / epi-brassi. / cell; $\mu \mathrm{g} \mathrm{mg} \mathrm{C}^{-1}$ and $\mathrm{pg} \mathrm{cell}^{-1}$ ) in Phaeodactylum tricornutum, Rhodomonas sp. and Emiliania huxleyi; carbon-normalized and per-cell contents of $\mathrm{C}_{37}-\mathrm{C}_{39}$ total alkenones (Alkenones / POC and Alkenones / cell); per-cell contents of $\mathrm{C}_{37}$ alkenones $\left(\mathrm{C}_{37} /\right.$ cell), $\mathrm{C}_{38}$ alkenones $\left(\mathrm{C}_{38} /\right.$ cell), $\mathrm{C}_{38}$ ethyl ketones $\left(\mathrm{C}_{38}\right.$ Et / cell) and $\mathrm{C}_{38}$ methyl ketones $\left(\mathrm{C}_{38} \mathrm{Me} /\right.$ cell); and the ratios of $\mathrm{C}_{37} / \mathrm{C}_{38}$ alkenones and $\mathrm{C}_{38} \mathrm{Et} / \mathrm{C}_{38} \mathrm{Me}\left(\mathrm{C}_{38} \mathrm{Et} / \mathrm{Me}\right)$ in E. huxleyi. Significant $p$ values are shown in bold; $T$ represents temperature, and $\mathrm{N}: \mathrm{P}$ represents $\mathrm{N}$ to $\mathrm{P}$ supply ratios.

\begin{tabular}{|c|c|c|c|c|c|c|c|}
\hline Species & Variable & Factor & Coefficient & SE & $t$ & $p$ & $n$ \\
\hline \multirow[t]{8}{*}{ P. tricornutum } & \multirow[t]{4}{*}{ Brassi. / epi-brassi. / cell } & Intercept & -1.482 & 0.077 & -19.187 & $<0.001$ & 50 \\
\hline & & $T$ & 0.010 & 0.004 & 2.842 & 0.007 & \\
\hline & & $p \mathrm{CO}_{2}$ & $<0.001$ & $<0.001$ & 1.656 & 0.105 & \\
\hline & & $\mathrm{N}: \mathrm{P}$ & 0.003 & 0.001 & 4.199 & $<0.001$ & \\
\hline & \multirow[t]{4}{*}{ Brassi. / epi-brassi. / POC } & Intercept & 7.043 & 0.820 & 8.589 & $<0.001$ & 52 \\
\hline & & $T$ & 0.040 & 0.039 & 1.021 & 0.312 & \\
\hline & & $p \mathrm{CO}_{2}$ & $<0.001$ & $<0.001$ & 0.452 & 0.653 & \\
\hline & & $\mathrm{N}: \mathrm{P}$ & -0.012 & 0.008 & -1.464 & 0.150 & \\
\hline \multirow[t]{8}{*}{ Rhodomonas sp. } & \multirow[t]{4}{*}{ Brassi. / epi-brassi. / cell } & Intercept & -0.388 & 0.103 & -3.750 & $<0.001$ & 51 \\
\hline & & $T$ & -0.006 & 0.005 & -1.290 & 0.203 & \\
\hline & & $p \mathrm{CO}_{2}$ & $<0.001$ & $<0.001$ & 0.368 & 0.714 & \\
\hline & & $\mathrm{N}: \mathrm{P}$ & 0.002 & 0.001 & 2.092 & 0.042 & \\
\hline & \multirow[t]{4}{*}{ Brassi. / epi-brassi. / POC } & Intercept & 1.484 & 0.186 & 7.987 & $<0.001$ & 54 \\
\hline & & $T$ & 0.012 & 0.008 & 1.435 & 0.158 & \\
\hline & & $p \mathrm{CO}_{2}$ & $<0.001$ & $<0.001$ & -2.706 & 0.009 & \\
\hline & & $\mathrm{N}: \mathrm{P}$ & -0.002 & 0.002 & -0.868 & 0.389 & \\
\hline \multirow[t]{28}{*}{ E. huxleyi } & \multirow[t]{4}{*}{ Brassi. / epi-brassi. / cell } & Intercept & -1.189 & 0.131 & -9.085 & $<0.001$ & 54 \\
\hline & & $T$ & -0.003 & 0.006 & -0.450 & 0.655 & \\
\hline & & $p \mathrm{CO}_{2}$ & $<0.001$ & $<0.001$ & 1.485 & 0.144 & \\
\hline & & $\mathrm{N}: \mathrm{P}$ & 0.003 & 0.001 & 2.367 & $\mathbf{0 . 0 2 2}$ & \\
\hline & \multirow[t]{4}{*}{ Brassi. / epi-brassi. / POC } & Intercept & 5.860 & 0.709 & 8.262 & $<0.001$ & 54 \\
\hline & & & 0.081 & 0.033 & 2.447 & 0.018 & \\
\hline & & $p \mathrm{CO}_{2}$ & $<0.001$ & $<0.001$ & -0.203 & 0.840 & \\
\hline & & $\mathrm{N}: \mathrm{P}$ & -0.043 & 0.007 & -6.017 & $<0.001$ & \\
\hline & \multirow[t]{4}{*}{ Alkenones / cell } & Intercept & 0.143 & 0.126 & 1.134 & 0.263 & 52 \\
\hline & & $T$ & -0.009 & 0.006 & -1.452 & 0.153 & \\
\hline & & $p \mathrm{CO}_{2}$ & $<0.001$ & $<0.001$ & 1.663 & 0.103 & \\
\hline & & $\mathrm{N}: \mathrm{P}$ & 0.006 & 0.001 & 4.973 & $<\mathbf{0 . 0 0 1}$ & \\
\hline & \multirow[t]{4}{*}{ Alkenones / POC } & Intercept & 122.935 & 25.130 & 4.892 & $<0.001$ & 52 \\
\hline & & $T$ & 0.468 & 1.183 & 0.396 & 0.694 & \\
\hline & & $p \mathrm{CO}_{2}$ & -0.001 & 0.006 & -0.090 & 0.929 & \\
\hline & & $\mathrm{N}: \mathrm{P}$ & -0.172 & 0.258 & -0.665 & 0.509 & \\
\hline & \multirow[t]{4}{*}{$\mathrm{C}_{37} /$ cell } & Intercept & -0.192 & 0.121 & -1.591 & 0.118 & 52 \\
\hline & & $T$ & -0.004 & 0.006 & -0.772 & 0.444 & \\
\hline & & $p \mathrm{CO}_{2}$ & $<0.001$ & $<0.001$ & 1.509 & 0.138 & \\
\hline & & $\mathrm{N}: \mathrm{P}$ & 0.007 & 0.001 & 5.466 & $<\mathbf{0 . 0 0 1}$ & \\
\hline & \multirow[t]{4}{*}{$\mathrm{C}_{38} /$ cell } & Intercept & -0.181 & 0.134 & -1.351 & 0.183 & 52 \\
\hline & & $T$ & -0.012 & 0.006 & -1.922 & 0.061 & \\
\hline & & $p \mathrm{CO}_{2}$ & $<0.001$ & $<0.001$ & 1.765 & 0.084 & \\
\hline & & $\mathrm{N}: \mathrm{P}$ & 0.006 & 0.001 & 4.356 & $<\mathbf{0 . 0 0 1}$ & \\
\hline & \multirow[t]{4}{*}{$\mathrm{C}_{38} \mathrm{Et} /$ cell } & Intercept & -0.509 & 0.150 & -3.396 & $<0.001$ & 52 \\
\hline & & $T$ & -0.004 & 0.007 & -0.569 & 0.572 & \\
\hline & & $p \mathrm{CO}_{2}$ & $<0.001$ & $<0.001$ & 1.512 & 0.137 & \\
\hline & & $\mathrm{N}: \mathrm{P}$ & 0.006 & 0.002 & 4.054 & $<0.001$ & \\
\hline
\end{tabular}


Table 1. Continued.

\begin{tabular}{|c|c|c|c|c|c|c|c|}
\hline Species & Variable & Factor & Coefficient & SE & $t$ & $p$ & $n$ \\
\hline \multirow[t]{12}{*}{ E. huxleyi } & \multirow[t]{4}{*}{$\mathrm{C}_{38} \mathrm{Me} /$ cell } & Intercept & -0.305 & 0.113 & -2.702 & 0.010 & 52 \\
\hline & & $T$ & -0.032 & 0.005 & -6.045 & $<0.001$ & \\
\hline & & $p \mathrm{CO}_{2}$ & $<0.001$ & $<0.001$ & 2.181 & $\mathbf{0 . 0 3 4}$ & \\
\hline & & $\mathrm{N}: \mathrm{P}$ & 0.005 & 0.001 & 4.648 & $<0.001$ & \\
\hline & \multirow[t]{4}{*}{$\mathrm{C}_{37} / \mathrm{C}_{38}$} & Intercept & 0.922 & 0.084 & 11.010 & $<0.001$ & 54 \\
\hline & & $T$ & 0.024 & 0.004 & 6.094 & $<0.001$ & \\
\hline & & $p \mathrm{CO}_{2}$ & $<0.001$ & $<0.001$ & -2.179 & $\mathbf{0 . 0 3 4}$ & \\
\hline & & $\mathrm{N}: \mathrm{P}$ & 0.003 & 0.001 & 3.348 & 0.002 & \\
\hline & \multirow[t]{4}{*}{$\mathrm{C}_{38} \mathrm{Et} / \mathrm{Me}$} & Intercept & 0.895 & 0.091 & 9.872 & $<0.001$ & 54 \\
\hline & & $T$ & -0.028 & 0.004 & -6.524 & $<0.001$ & \\
\hline & & $p \mathrm{CO}_{2}$ & $<0.001$ & $<0.001$ & 0.464 & 0.644 & \\
\hline & & $\mathrm{N}: \mathrm{P}$ & -0.001 & 0.001 & -0.749 & 0.457 & \\
\hline
\end{tabular}
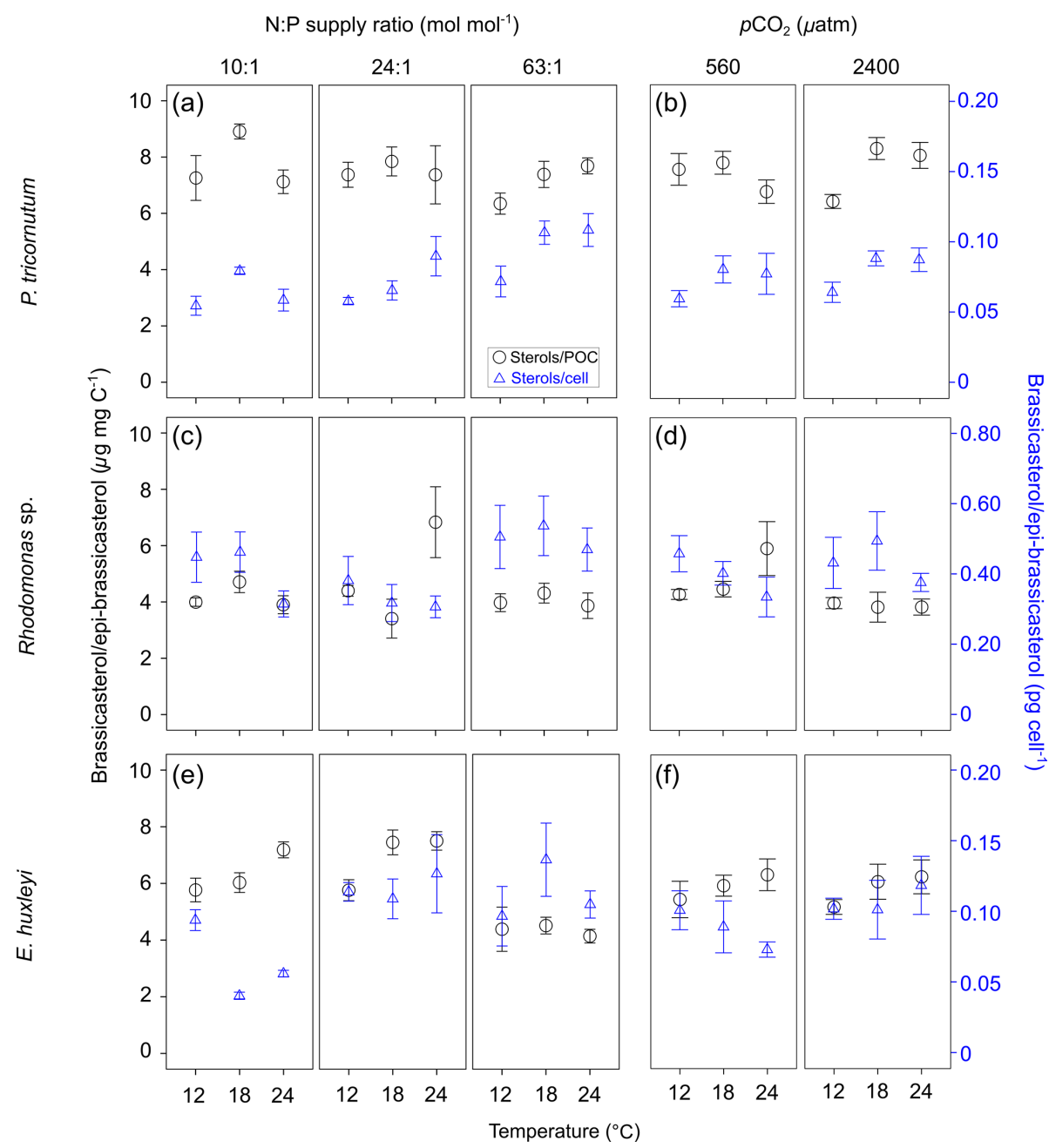

Figure 1. Carbon-normalized (open circles) and per-cell (open triangles) contents of brassicasterol / epi-brassicasterol (mean $\pm \mathrm{SE}$; $\mu \mathrm{g} \mathrm{mg} \mathrm{C}-1$ and $\mathrm{pg} \mathrm{cell}^{-1}$, respectively) in response to the changes in temperature, $\mathrm{N}: \mathrm{P}$ supply ratios and p $\mathrm{CO}_{2}$ in Phaeodactylum tricornutum (a, b), Rhodomonas sp. (c, d) and Emiliania huxleyi (e, f). Triplicates were set for each treatment. 


\subsection{Responses of alkenones to environmental changes}

Total alkenone content per cell in E. huxleyi increased with increasing $\mathrm{N}: \mathrm{P}$ supply ratios (Fig. 2a; bold letters in Tables 1; S4). However, carbon-normalized contents of total alkenones showed nonsignificant responses to changes in temperature, $\mathrm{N}$ : $\mathrm{P}$ supply ratios and $p \mathrm{CO}_{2}$.

$\mathrm{C}_{37} / \mathrm{C}_{38}$ alkenone ratios responded significantly to all three environmental factors (bold letters in Table 1), showing a clear increase with increasing temperature, a higher value under the lowest and highest $\mathrm{N}: \mathrm{P}$ supply ratios, and a slight decrease at high $p \mathrm{CO}_{2}$ (Fig. $2 \mathrm{c}$ and d). $\mathrm{C}_{38} \mathrm{Et} / \mathrm{Me}$ ratios had significant responses only to temperature changes, which were clearly higher at the highest temperature (Fig. 2e and $\mathrm{f}$ ).

\subsection{Comparisons of sterol, alkenone and fatty acid responses}

PCA extracted four axes with eigenvalues $>1$, and the first two axes in PCA explained $44.1 \%$ of total variance (Table S5). PC axis 1 explains $26.4 \%$ of the total variance and largely differentiates between the highest $\left(\mathrm{N}: \mathrm{P}=63: 1 \mathrm{~mol} \mathrm{~mol}^{-1}\right)$ and lower $\mathrm{N}: \mathrm{P}$ treatments $\left(\mathrm{N}: \mathrm{P}=10: 1\right.$ and $\left.24: 1 \mathrm{~mol} \mathrm{~mol}^{-1}\right)$. Along $\mathrm{PC}$ axis $1, \mathrm{~N}: \mathrm{P}$ supply ratios correlated positively with carbon-normalized contents of TFAs in P. tricornutum and Rhodomonas sp. but negatively with brassicasterol / epi-brassicasterol in E. huxleyi (Fig. 3). PC axis 2 (17.7\% of the total variance) differentiates between the highest and both colder temperature treatments, along which temperature showed positive correlations with brassicasterol / epi-brassicasterol in Rhodomonas sp. and alkenones in E. huxleyi but a negative correlation with TFAs in E. huxleyi. Both Dim1 and Dim2 loadings for $p \mathrm{CO}_{2}$ were very low (0.185 and 0.151 , respectively), showing a weaker effect of $p \mathrm{CO}_{2}$ on lipid biomarkers compared to temperature and $\mathrm{N}$ : $\mathrm{P}$ supply ratios. Along $\mathrm{PC}$ axis $2, p \mathrm{CO}_{2}$ plays a negative role particularly on TFAs in E. huxleyi, while the contribution of $p \mathrm{CO}_{2}$ to other lipid biomarkers was weak.

\section{Discussion}

To our knowledge, this is the first study to disentangle the effects of multiple environmental drivers on sterol and alkenone productions and to compare the responses of sterols, alkenones and FAs in marine phytoplankton. The mean percent changes of the three lipid biomarkers were elucidated (Table 2), particularly showing obvious changes in per-cell lipid contents which underly specific modes of biosynthesis. Furthermore, the PCA results highlight that the responses of TFA carbon-normalized contents to $\mathrm{N}: \mathrm{P}$ supply ratios were opposite to that of brassicasterol / epibrassicasterol and alkenones (Fig. 3; Table S5), e.g., strong positive correlations of TFAs with $\mathrm{N}: \mathrm{P}$ ratios in $P$. tricornutum and Rhodomonas sp. but negative ones of brassicast- erol / epi-brassicasterol with $\mathrm{N}$ : P ratios in E. huxleyi. Also, carbon-normalized alkenone contents in E. huxleyi correlated positively with temperature, but TFAs contents showed a negative correlation with temperature. Such variable responses of the three classes of lipid biomarkers can be attributed to their specific physiological functions and biosynthetic pathways (Riebesell et al., 2000). Carbon-normalized contents of FAs were particularly sensitive to environmental changes, because FAs can be incorporated into different types of lipids and thus play multiple roles within the cells such as energy storage, membrane components and metabolic regulations (Guschina and Harwood, 2009; Van Mooy et al., 2009). Conversely, less pronounced changes in carbon-normalized contents of sterols and alkenones may reflect their major roles in membrane functions and energy storage, respectively. The varying production of lipid biomarkers indicate potential changes of energy flow in marine food webs in response to ocean-related global change.

\subsection{Sterol and alkenone composition}

Brassicasterol / epi-brassicasterol was the only major sterol in the three algal species under wide ranges of temperature, $\mathrm{N}$ : $\mathrm{P}$ supply ratios and $p \mathrm{CO}_{2}$. It is well established that the diversity of sterols is low in most phytoplankton species (Martin-Creuzburg and Merkel, 2016; Volkman, 2016). The predominance of brassicasterol / epi-brassicasterol has been reported for P. tricornutum (Orcutt and Patterson, 1975; Ballantine et al., 1979; Rampen et al., 2010), Rhodomonas (Dunstan et al., 2005; Chen et al., 2011) and E. huxleyi (Volkman et al., 1981; Riebesell et al., 2000). A few other minor sterols have been reported, but they were not detected or below detection in our study, such as cholesterol, 24methylcholest-5-en-3 $\beta$-ol, and cholesta-5,22-dienol in P. tricornutum (Ballantine et al., 1979; Véron et al., 1996; Cvejić and Rohmer, 2000) and cholesterol and 24-methylcholesta$5,7,22$-trien-3 $\beta$-ol in Rhodomonas/Proteomonas sp. (Dunstan et al., 2005) and E. huxleyi (Yamamoto et al., 2000; Sawada and Shiraiwa, 2004; Mausz and Pohnert, 2015).

Alkenones were only observed in E. huxleyi in our study, consistent with previous results showing that these compounds were only synthesized by a few haptophytes including E. huxleyi (Volkman et al., 1980b; Volkman et al., 1998). The alkenone composition of E. huxleyi was characterized by the presence of four pairs of isomers, including eight alkenone compounds (Table S4) (Marlowe et al., 1984; Riebesell et al., 2000; Sachs et al., 2016). Moreover, higher abundance of several alkenone components have been also observed in some E. huxleyi strains under certain culture conditions, e.g., $\mathrm{C}_{37: 4} \mathrm{Me}$ in the strain 1742 (Eltgroth et al., 2005) or at low temperatures (our study; Prahl and Wakeham, 1987). In addition, two other compounds $C_{38: 4}$ Et and $C_{38: 4}$ Me were also found in one E. huxleyi strain (Marlowe et al., 1984). 

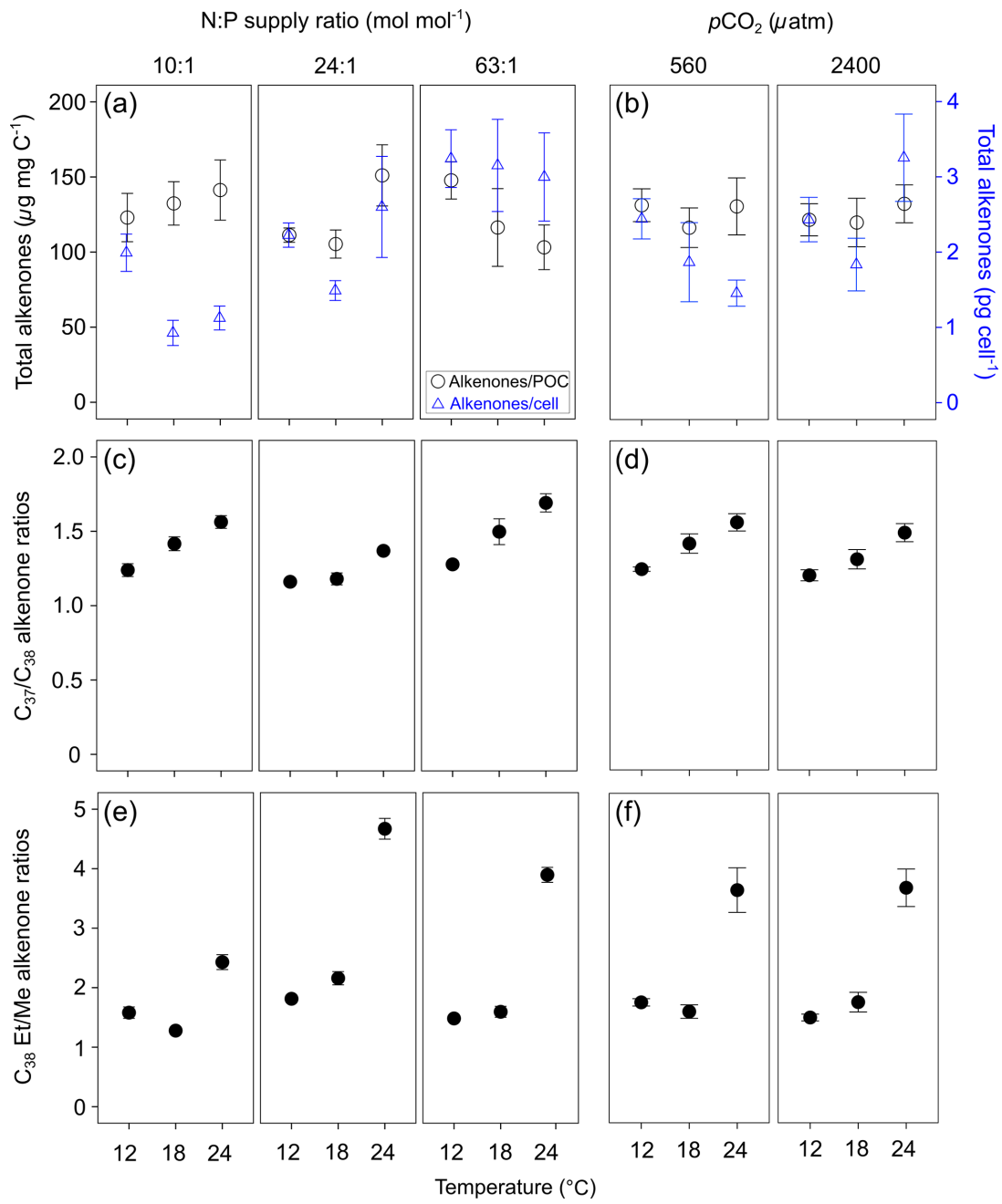

Figure 2. Carbon-normalized (open circles) and per-cell (open triangles) contents of $\mathrm{C}_{37}-\mathrm{C}_{39}$ total alkenones (mean $\pm \mathrm{SE}$; $\mu \mathrm{g} \mathrm{mg} \mathrm{C}^{-1}$ and pg cell ${ }^{-1}$, respectively) (a, b), $\mathrm{C}_{37} / \mathrm{C}_{38}$ alkenone ratios $(\mathbf{c}, \mathbf{d})$ and $\mathrm{C}_{38}$ ethyl $/ \mathrm{C}_{38}$ methyl ratios $\left(\mathrm{C}_{38} \mathrm{Et} / \mathrm{Me}\right.$ alkenone ratios) $(\mathbf{e}, \mathbf{f})$ in Emiliania huxleyi in response to the changes in temperature, $\mathrm{N}: \mathrm{P}$ supply ratios and $p \mathrm{CO}_{2}$. Triplicates were set for each treatment.

Collectively, the results above highlight the similarity of sterol and alkenone composition in algal species in our study with those in conspecifics or congeneric phytoplankters in previous studies. Sterol and alkenone composition can vary between algal strains and can be affected by environmental changes (Conte et al., 1994; Volkman, 2003), which may explain the differences between our findings and previous results. In the following section, specific response patterns of brassicasterol / epi-brassicasterol and alkenones are evaluated and quantified, which are further compared with FA responses under changing temperature, $\mathrm{N}$ : $\mathrm{P}$ supply ratios and $p \mathrm{CO}_{2}$.

\subsection{Responses of brassicasterol / epi-brassicasterol contents}

Increasing temperature caused an overall $12 \%$ increase in carbon-normalized contents of brassicasterol / epibrassicasterol in E. huxleyi but nonsignificant changes in P. tricornutum and Rhodomonas sp. (Tables 1 and 2). Consistent with our findings, positive correlations between increasing temperature and sterol carbon-normalized contents have been observed in the dinoflagellates Karenia mikimotoi and Prorocentrum minimum (Ding et al., 2019) and the green alga Scenedesmus quadricauda (Piepho et al., 2012). High sterol contents at high temperature could be predicted based on its biochemical function, because increasing levels of sterols can reduce membrane fluidity to enable an organism's functional activity as temperature increases (Ford and Barber, 1983). 


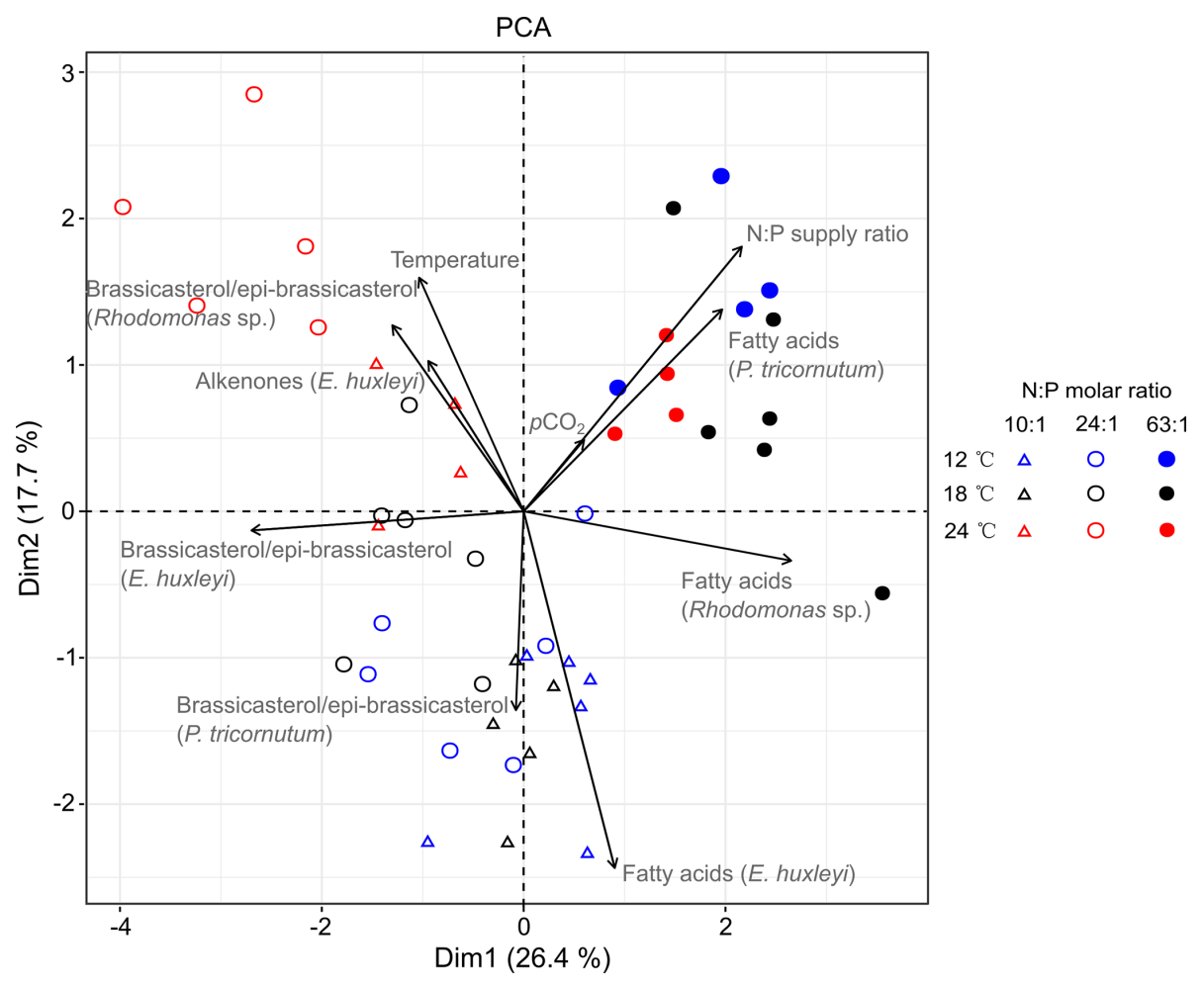

Figure 3. PCA biplot based on the carbon-normalized contents of the major sterol (brassicasterol / epi-brassicasterol) and total fatty acids ( $\mu \mathrm{g} \mathrm{mg} \mathrm{C}^{-1}$ ) in Phaeodactylum tricornutum, Rhodomonas sp. and Emiliania huxleyi, as well as $\mathrm{C}_{37}-\mathrm{C}_{39}$ total alkenones in E. huxleyi under different temperatures, $\mathrm{N}: \mathrm{P}$ supply ratios and $p \mathrm{CO}_{2}$. Blue, black and red symbols represent 12,18 and $24^{\circ} \mathrm{C}$, respectively. Open triangles, open circles and closed circles represent N : P molar ratios of 10:1, $24: 1$ and 63:1, respectively. The first two dimensions (Dim1 and Dim2) account for $44.1 \%$ of the total variance. The length of each vector reflects the combined loading of each variable in the first two dimensions (Table S5).

Enhanced partial $\mathrm{CO}_{2}$ pressure caused a $21 \%$ decrease in carbon-normalized brassicasterol / epi-brassicasterol contents in Rhodomonas sp. and nonsignificant responses in $P$. tricornutum and E. huxleyi; however, per-cell contents of brassicasterol / epi-brassicasterol and POC showed nonsignificant changes in all three species (Tables 1 and 2). Minor effects of $\mathrm{CO}_{2}$ concentration on per-cell contents of sterols have been observed in another strain of E. huxleyi (PML B92/11) (Riebesell et al., 2000) and the Chlorophyceae D. viridis (Gordillo et al., 1998). While the mechanism underlying sterol responses to $p \mathrm{CO}_{2}$ is still unclear, our results indicate that enhanced $p \mathrm{CO}_{2}$ did not induce substantial changes in per-cell contents of sterols in phytoplankton due to the role of sterols in membrane composition and functions (Riebesell et al., 2000). Nevertheless, enhanced $p \mathrm{CO}_{2}$ might change carbon metabolism in phytoplankton (Gordillo et al., 2001), as revealed by variable carbon-normalized contents of brassicasterol / epi-brassicasterol in Rhodomonas sp. in our study.

$\mathrm{N}$ and $\mathrm{P}$ deficiency caused overall $8 \%$ and $37 \%$ decreases in carbon-normalized brassicasterol / epi-brassicasterol contents, respectively, in E. huxleyi but nonsignificant changes in other two species (Tables 1 and 2). Carbon-normalized or dry-weight contents of sterols in phytoplankton generally reduced in response to $\mathrm{N}$ or P deficiency (Breteler et al., 2005; Piepho et al., 2010; Ding et al., 2019). Furthermore, the relatively higher per-cell contents of sterols in response to $\mathrm{P}$ deficiency than $\mathrm{N}$ deficiency have been also found in the three species in this study and in the freshwater diatom Stephanodiscus minutulus (Lynn et al., 2000). Lipid modifications triggered by nutrient deficiency have been well studied in the plant Arabidopsis and more recently elucidated in typical phytoplankters (Van Mooy et al., 2009; Abida et al., 2015; Shemi et al., 2016). In P. tricornutum, $\mathrm{N}$ deficiency exerted more severe stress on membrane glycerolipids than P deficiency, which caused a stepwise adaptive response, resulting in undetectable phospholipids and instead the increase in the synthesis of non-phosphorus lipids (Abida et al., 2015). Also in plants, $\mathrm{P}$ deficiency resulted in the replacement of phospholipids by non-phosphorous glycolipids such as glucosylceramide, sterol glucoside and acylated sterol glucoside (Siebers et al., 2015). Consequently, sterols are synthesized and accumulate in the plasma membrane in response to $\mathrm{P}$ deficiency. Thus, $\mathrm{N}$ deficiency may inhibit the capacity of the cells to synthesize sterols, while upon P deficiency membrane glycerolipid remodeling with the accumulation of non- 
Table 2. The mean percent differences in carbon-normalized and per-cell contents of brassicasterol/epi-brassicasterol (brassi./epi-

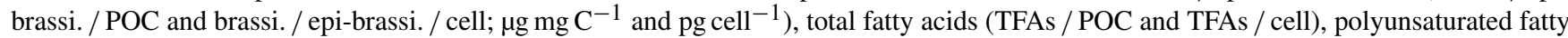
acids (PUFAs / POC and PUFAs / cell), and per-cell contents of particulate organic carbon (POC / cell) in Phaeodactylum tricornutum, Rhodomonas sp., and Emiliania huxleyi; carbon-normalized and per-cell contents of total alkenones (Alkenones / POC and Alkenones / cell), and per-cell contents of $\mathrm{C}_{37}$ alkenones $\left(\mathrm{C}_{37} /\right.$ cell $), \mathrm{C}_{38}$ alkenones $\left(\mathrm{C}_{38} /\right.$ cell $), \mathrm{C}_{38}$ ethyl ketones $\left(\mathrm{C}_{38} \mathrm{Et} /\right.$ cell $)$, and $\mathrm{C}_{38}$ methyl ketones $\left(\mathrm{C}_{38}\right.$ $\mathrm{Me} /$ cell $)$ in E. huxleyi; $\mathrm{C}_{37} / \mathrm{C}_{38}$ alkenone ratios $\left(\mathrm{C}_{37} / \mathrm{C}_{38}\right)$ and $\mathrm{C}_{38}$ ethyl $/ \mathrm{C}_{38}$ methyl ratios $\left(\mathrm{C}_{38}\right.$ Et / Me $)$ in E. huxleyi between cold and warm treatments, under $\mathrm{N}$ and $\mathrm{P}$ deficiency (-N and $-\mathrm{P})$ and enhanced $p \mathrm{CO}_{2}$ conditions. Only significant changes are shown according to GLMMs (Table 1).

\begin{tabular}{|c|c|c|c|c|c|c|}
\hline \multirow[b]{2}{*}{ Lipids or POC } & \multirow[b]{2}{*}{ Species } & \multicolumn{5}{|c|}{ Effect } \\
\hline & & Warming & $-N$ & $-P$ & $\begin{array}{c}\text { Enhanced } \\
\mathrm{pCO}_{2}\end{array}$ & Interaction \\
\hline \multirow{4}{*}{ Brassi./epi-brassi./cell } & P. tricornutum & $+23 \%$ & $-7 \%$ & $+37 \%$ & & \\
\hline & Rhodomonas sp. & & $+21 \%$ & $+51 \%$ & & \\
\hline & E. huxleyi & & $-46 \%$ & $-3 \%$ & & \\
\hline & P. tricornutum & & & & & \\
\hline \multirow[t]{2}{*}{ Brassi./epi-brassi./POC } & Rhodomonas sp. & & & & $-21 \%$ & \\
\hline & E. huxleyi & $+12 \%$ & $-8 \%$ & $-37 \%$ & & \\
\hline Alkenones/cell & E. huxleyi & & $-35 \%$ & $+49 \%$ & & \\
\hline Alkenones/POC & E. huxleyi & & & & & \\
\hline $\mathrm{C}_{37} /$ cell & E. huxleyi & & $-34 \%$ & $+59 \%$ & & \\
\hline $\mathrm{C}_{38} /$ cell & E. huxleyi & & $-38 \%$ & $+37 \%$ & & \\
\hline $\mathrm{C}_{38}$ Et/cell & E. huxleyi & & $-47 \%$ & $+27 \%$ & & \\
\hline $\mathrm{C}_{38} \mathrm{Me} /$ cell & E. huxleyi & $-39 \%$ & $-16 \%$ & $+62 \%$ & $+25 \%$ & \\
\hline $\mathrm{C}_{37} / \mathrm{C}_{38}$ & E. huxleyi & $+15 \%$ & $+13 \%$ & $+21 \%$ & $-6 \%$ & \\
\hline $\mathrm{C}_{38} \mathrm{Et} / \mathrm{Me}$ & E. huxleyi & $+82 \%$ & & & & \\
\hline \multirow{3}{*}{ TFAs/cell } & P. tricornutum ${ }^{\mathrm{a}}$ & $+19 \%$ & $+1 \%$ & $+77 \%$ & & \\
\hline & Rhodomonas sp. $^{\text {a }}$ & & $+124 \%$ & $+218 \%$ & & \\
\hline & E. huxleyi ${ }^{b}$ & $-29 \%$ & $-11 \%$ & $+72 \%$ & & \\
\hline \multirow{3}{*}{ TFAs/POC } & P. tricornutum ${ }^{\mathrm{a}}$ & & $+2 \%$ & $+12 \%$ & & \\
\hline & Rhodomonas sp. ${ }^{a}$ & & $+78 \%$ & $+108 \%$ & & \\
\hline & E. huxleyi ${ }^{\mathrm{b}}$ & $-22 \%$ & & & $-20 \%$ & \\
\hline \multirow{3}{*}{ PUFAs/cell } & P. tricornutum ${ }^{\mathrm{a}}$ & & $-4 \%$ & $+71 \%$ & & \\
\hline & Rhodomonas sp. ${ }^{\text {a }}$ & & $+86 \%$ & $+165 \%$ & & \\
\hline & E. huxleyi ${ }^{\mathrm{b}}$ & $-19 \%$ & $-9 \%$ & $+93 \%$ & & \\
\hline \multirow{3}{*}{ PUFAs/POC } & P. tricornutum ${ }^{\mathrm{a}}$ & $-20 \%$ & $-2 \%$ & $+9 \%$ & & $\mathrm{~T} \times \mathrm{N}: \mathrm{P}$ \\
\hline & Rhodomonas sp. ${ }^{a}$ & & $+58 \%$ & $+76 \%$ & & \\
\hline & E. huxleyi & & & & $-24 \%$ & \\
\hline \multirow{3}{*}{ POC/cell } & P. tricornutum ${ }^{\mathrm{a}}$ & $+23 \%$ & $-0.3 \%$ & $+64 \%$ & & \\
\hline & Rhodomonas sp. ${ }^{\text {a }}$ & $-12 \%$ & $+26 \%$ & $+59 \%$ & & $T \times N: P$ \\
\hline & E. huxleyi & $-8 \%$ & $-39 \%$ & $+50 \%$ & & $T \times N: P$ \\
\hline
\end{tabular}

a, b Data are from Bi et al. (2017, 2018), respectively.

phosphorous lipids may explain the relatively higher per-cell contents of sterols in response to $\mathrm{P}$ deficiency in our study.

In summary, our study shows that temperature, $\mathrm{N}: \mathrm{P}$ supply ratios and $p \mathrm{CO}_{2}$ had significant separate effects on per-cell and per-carbon contents of brassicasterol / epibrassicasterol in certain algal species. Previous studies have shown significant interactions of two environmental factors on carbon-normalized contents of sterols in phytoplankton (Piepho et al., 2012; Chen et al., 2019; Ding et al., 2019).
We here found potentially confounding effects of multiple environmental drivers on phytoplankton sterol contents. For example, the responses of E. huxleyi brassicasterol / epibrassicasterol carbon-normalized contents to increasing temperature varied with $\mathrm{N}$ : $\mathrm{P}$ supply ratios, i.e., an increase under lower $\mathrm{N}$ : $\mathrm{P}$ supply ratios, but no clear changes under the highest $\mathrm{N}: \mathrm{P}$ ratio (Fig. 1e), suggesting that nutrient availability may potentially alter the effects of warming on sterol contents in E. huxleyi. 


\subsection{Responses of alkenone contents and ratios}

Carbon-normalized contents of total alkenones showed nonsignificant responses to the changes in temperature, $\mathrm{N}: \mathrm{P}$ supply ratios or $p \mathrm{CO}_{2}$ in $E$. huxleyi (Table 1), which can be attributed to similar response patterns of per-cell contents of alkenones and POC (Table 2). We observed that per-cell contents of alkenones changed significantly in response to $\mathrm{N}$ and $\mathrm{P}$ deficiency but showed nonsignificant responses to warming or enhanced $p \mathrm{CO}_{2}$. In the following, the responses of percell contents of alkenones and the ratios of certain alkenone isomers are discussed.

$\mathrm{N}$ deficiency in semicontinuous $E$. huxleyi cultures grown at $20 \%$ of $\mu_{\max }$ led to a $35 \%$ decrease in per-cell contents of alkenones in our study (Table 2). However, all published culture studies we could find in which E. huxleyi was grown under $\mathrm{N}$ deficiency were performed with batch cultures and reported either an increase in per-cell alkenone contents or a nonsignificant change (Epstein et al., 1998; Prahl et al., 2003; Bakku et al., 2018; Wördenweber et al., 2018). Several possible explanations exist for these contradictory findings. An increase in growth rate has been shown to reduce alkenone concentrations $\left(\mathrm{ng} \mathrm{mL}{ }^{-1}\right)$ in continuous cultures of $E$. huxleyi (Sachs and Kawka, 2015). Thus, the higher growth rate of E. huxleyi (20\% of $\mu_{\max }$ ) in semicontinuous cultures in our study is a possible cause of lower alkenone contents compared to the batch culture studies where cells were harvested at or near the stationary phase of growth (i.e., growth rate approaching 0) (Epstein et al., 1998; Prahl et al., 2003; Bakku et al., 2018; Wördenweber et al., 2018). Because growth rate and growth phase strongly affect sterol contents (Sachs and Kawka, 2015; Chen et al., 2019), the conjunctions abovedescribed may change if the maximum growth rates of batch cultures were used for comparison. In addition, phytoplankton in a continuous culture has a constant growth rate under a given dilution rate, while the growth rate at the stationary phase of a batch culture is zero. Thus, energy-availability for sterol remodeling differs between the two culture systems. Contradictory results obtained in batch and semicontinuous cultures could indicate different alkenone contents produced by $E$. huxleyi during the bloom period and summertime growth of this species, respectively (Lampert and Sommer, 2007). Another possibility is that gene complements within the species of $E$. huxleyi vary considerably, which may explain different phenotypic variations, including differences in $\mathrm{N}$ and $\mathrm{P}$ uptake in this species (Read et al., 2013). $\mathrm{N}$ deficiency severely impairs the synthesis of nucleotides, amino acids and ultimately all enzymatic machinery, consequently resulting in a decrease of most central metabolites (Wördenweber et al., 2018). Intense lipid turnover with the reduction of most central metabolites have been reported in E. huxleyi under $\mathrm{N}$ deficiency based on transcriptomic and metabolomic studies (Rokitta et al., 2014; Wördenweber et al., 2018), which may also result in lower per-cell alkenone contents in our study.
In contrast, $P$ deficiency caused an increase (49\%) in percell contents of alkenones in E. huxleyi (Table 2), as well as in other strains and life-cycle stages of E. huxleyi (Wördenweber et al., 2018). Experimental data presented here agree with a metabolic model predicted from transcriptomic data (Rokitta et al., 2016) and the findings in a comprehensive metabolomics study showing a significant accumulation of several key metabolites, especially neutral lipids such as triacylglycerols, alkenones and alkenes in response to $\mathrm{P}$ deficiency (Wördenweber et al., 2018). E. huxleyi contains only very small amounts of triacylglycerols and hence alkenones have been suggested to have a storage role (Volkman et al., 1980c; Bell and Pond, 1996; Eltgroth et al., 2005). Our results support this view and suggest that $\mathrm{P}$ deficiency can induce the accumulation of alkenones which can serve as storage molecules in E. huxleyi cells. The increased abundance of metabolites in response to $\mathrm{P}$ deficiency is likely derived from the arrest of cell-cycling due to decreased nucleic acid synthesis, and the reduction equivalents are preserved by lipogenesis as enzymatic functionality (Wördenweber et al., 2018).

The carbon chain-length distribution of alkenones $\left(\mathrm{C}_{37} / \mathrm{C}_{38}\right.$ alkenone ratios) showed a $13 \%-21 \%$ increase from the cold to warm treatments and in response to $\mathrm{N}$ and $\mathrm{P}$ deficiency and a slight decrease $(6 \%)$ with enhanced $p \mathrm{CO}_{2}$ (Tables 1 and 2). Previous studies have shown that $\mathrm{C}_{37} / \mathrm{C}_{38}$ alkenone ratios not only varied with temperature and physiological stages (such as growth stage) but also differed between alkenone-producing species (Conte et al., 1998; Pan and Sun, 2011; Nakamura et al., 2014). In agreement with our findings, a slight increase in $\mathrm{C}_{37} / \mathrm{C}_{38}$ alkenone ratios at higher temperatures has been also found in four $E$. huxleyi strains in exponential phase cultures (Conte et al., 1998). In contrast to our results, it has been reported lower $\mathrm{C}_{37} / \mathrm{C}_{38}$ alkenone ratios occurred under nutrient deficiency at the stationary phase of E. huxleyi in comparison to those at the exponential phase (Conte et al., 1998; Pan and Sun, 2011). As discussed above, different culturing approaches may cause conflicting results in different studies, as the effects of nutrient deficiency and growth rate cannot be well distinguished in the batch approach. The proposed biosynthetic pathways of classical $\mathrm{C}_{37}-\mathrm{C}_{40}$ alkenones show that biosynthesis of $\mathrm{C}_{37} \mathrm{Me}$ involves chain elongation with malonylCoA, while $\mathrm{C}_{38}$ Et compounds are formed by the condensation of methylmalonyl-CoA; $\mathrm{C}_{38}$ Me compounds are produced after the involvement of an additional $\alpha$-oxidation (Rontani et al., 2006). Our results suggest that warming, $\mathrm{N}$ and $\mathrm{P}$ deficiency, and enhanced $p \mathrm{CO}_{2}$ may have independent effects on the synthesis of $\mathrm{C}_{37} \mathrm{Me}$ and $\mathrm{C}_{38}$ alkenones, which ultimately result in changes in $\mathrm{C}_{37} / \mathrm{C}_{38}$ ratios.

The relative abundance of $\mathrm{C}_{38}$ homologs $\left(\mathrm{C}_{38} \mathrm{Et} / \mathrm{Me}\right.$ ratios) showed an $82 \%$ increase from the cold to warm treatments (Tables 1 and 2). The prominent increase in $\mathrm{C}_{38}$ Et / Me ratios resulted from nonsignificant changes in percell contents of $\mathrm{C}_{38} \mathrm{Et}$ and the decrease in $\mathrm{C}_{38} \mathrm{Me}$. An 
increase in $\mathrm{C}_{38} \mathrm{Et} / \mathrm{Me}$ ratios with increasing temperatures has been found in four E. huxleyi strains in mid-exponential phase of batch cultures (Conte et al., 1998). More importantly, our experimental results agree well with the findings in the sedimentary records back to $\sim 120.5 \mathrm{Ma}$ (Brassell et al., 2004), showing the absence of all $\mathrm{C}_{38}$ Me but the occurrence of $\mathrm{C}_{38}$ Et in Cretaceous sediments (warm climate, indicating a high $\mathrm{C}_{38} \mathrm{Et} / \mathrm{Me}$ ratio) but the presence of $\mathrm{C}_{38} \mathrm{Me}$ from Cretaceous to Quaternary ages (warm to cold climate, suggesting a potentially declined $\mathrm{C}_{38} \mathrm{Et} / \mathrm{Me}$ ratio). The strong increases in $\mathrm{C}_{38} \mathrm{Et} / \mathrm{Me}$ ratios with warming in our study may reflect the differences in biosynthetic pathways between $\mathrm{C}_{38}$ Et and $\mathrm{C}_{38}$ Me (Rontani et al., 2006). Therefore, the distribution of alkenones in sediments over time can be linked to evolutionary adaption of alkenone biosynthesis in response to global climate change (Brassell, 2014).

The results discussed above show significant changes in per-cell contents of alkenones in response to $\mathrm{N}$ and $\mathrm{P}$ deficiency, indicating the important role of alkenones as storage molecules. Another type of biomolecules, alkenoates, has been identified in E. huxleyi and may biochemically link with alkenones (Marlowe et al., 1984; Conte et al., 1994). However, alkenoates were converted to FAs by saponification in our sample preparation steps and thus not evaluated. There might be interesting variations in alkenone / alkenoate ratios with changing multiple environmental conditions, which can be assessed in future studies.

\subsection{Implications for ecology and biogeochemistry}

There has been evidence that carbon allocation in algal cells is highly responsive to environmental changes (Palmucci et al., 2011; Halsey and Jones, 2015). Our new study demonstrated that, under future ocean scenarios (warming, $\mathrm{N}$ and $\mathrm{P}$ deficiency and enhanced $p \mathrm{CO}_{2}$ ), carbon-normalized contents of brassicasterol / epi-brassicasterol, alkenones and FAs have differential responses, i.e., significant but nonsystematic changes in sterols and FAs, and nonsignificant changes in alkenones (Table 1). Our results further suggest rearrangements of cellular carbon pools under future ocean scenarios, and such variations would have important impacts on marine ecological functions and biogeochemical cycles.

Our study revealed an overall decrease $(\sim 20 \%)$ in carbon-normalized contents of brassicasterol/epibrassicasterol in Rhodomonas sp. and E. huxleyi under ocean-related global change scenarios (Table 2). The low availability or absence of dietary sterols has been shown to constrain growth, reproduction and survival in Daphnia (Martin-Creuzburg et al., 2005; Martin-Creuzburg and von Elert, 2009a) and development and egg production in copepods (Hassett, 2004; Klein-Breteler et al., 2005). The potential influence of sterol deficiency on ecosystem functioning is the reduction of carbon transfer efficiency across the autotroph-herbivore interface, leading to a low production of higher trophic levels (von Elert et al.,
2003; Martin-Creuzburg and von Elert, 2009b). Brassicasterol/epi-brassicasterol compounds are cholesterol precursors and can be converted to cholesterol by most crustaceans (Martin-Creuzburg and von Elert, 2009b; Kumar et al., 2018) and thus can efficiently support somatic growth of crustacean zooplankton such as Daphnia magna (Martin-Creuzburg et al., 2014). It is therefore possible that reduced brassicasterol/epi-brassicasterol under projected future ocean conditions may have deleterious ecological consequences in plankton communities, particularly where Rhodomonas or E. huxleyi is dominant.

Carbon-normalized contents of PUFAs showed an overall increase $(\sim 65 \%)$ in Rhodomonas sp. and an overall decrease $(\sim 10 \%-20 \%)$ in P. tricornutum and E. huxleyi (Table 2). FA composition and contents in phytoplankton have shown significant effects on zooplankton production and trophic carbon transfer from phytoplankton to zooplankton (MüllerNavarra et al., 2000; Jónasdóttir et al., 2009; Rossoll et al., 2012; Arndt and Sommer, 2014). An example of this is the positive effect of increased docosahexaenoic acid (22:6n3; DHA) content in the diatom Skeletonema marinoi on egg production rates of the calanoid copepod Acartia tonsa (Amin et al., 2011). These impacts of FA production remodeling have been discussed in detail in our previous studies (Bi et al., 2014, 2018; Bi and Sommer, 2020). The varying PUFA contents observed in the present study may thus potentially influence zooplankton nutrition. For example, an increase in PUFA contents in the diatoms in cold periods may have positive effects on zooplankton production; in contrast, a decrease in PUFA contents in E. huxleyi at enhanced $p \mathrm{CO}_{2}$ may reduce trophic transfer efficiency at the phytoplanktonzooplankton interface. Moreover, we found that the overall responses of brassicasterol / epi-brassicasterol were opposite to PUFAs in Rhodomonas sp., while both showed an overall decrease in E. huxleyi; only brassicasterol / epibrassicasterol decreased in P. tricornutum under future ocean scenarios (Table 2). Co-limitation of sterols and PUFAs has been well studied in a freshwater herbivore D. magna, showing a negative effect on the growth of this herbivore (MartinCreuzburg et al., 2009; Sperfeld et al., 2012; Marzetz et al., 2017). Less is known about how sterols and PUFAs regulate the performance of marine herbivorous zooplankton. The differential responses of sterols and PUFAs we observed may have tremendous implications for the study of marine food webs, especially in habitats where phytoplankton succession is highly dynamic with environmental changes.

Carbon-normalized contents of total alkenones in E. huxleyi showed nonsignificant changes (Table 2). E. huxleyi is mainly grazed by heterotrophic protists in the context of pelagic food webs (Braeckman et al., 2018; Nejstgaard et al., 1997). Also, early studies on copepod feeding clearly showed ingestion of E. huxleyi (Harris, 1994; Nejstgaard et al., 1997; Vermont et al., 2016) and excretion of alkenones (Volkman et al., 1980a), indicating faecal pellet transport of these compounds to sediments (Volkman et al., 1980a). In the 
present study, we observed nonsignificant changes in carbonnormalized contents of total alkenones in E. huxleyi under variable temperature, $\mathrm{N}: \mathrm{P}$ ratios and $p \mathrm{CO}_{2}$, demonstrating quantitative applicability of alkenones as proxies for $E$. huxleyi biomass in biogeochemical cycles.

From a paleoceanographic perspective, lipid biomarker data have been reported on the basis of both dry sediment weight and total organic carbon (TOC) content (Zimmerman and Canuel, 2002; Zhao et al., 2006; Xing et al., 2016). Dry sediments contain variable organic and inorganic components; thus, biomarker contents normalized to TOC can partially eliminate the influence of sedimentation rates and between-site or temporal changes in the amount of organic carbon deposition or preservation (Zimmerman and Canuel, 2002). The application of sediment biomarker contents for paleoproductivity reconstruction is based on two key assumptions: (1) relatively constant ratios of biomarker per cell or per POC in a specific phytoplankton group and (2) nonsignificant changes in biomarker/POC ratios during post production and deposition degradation. In laboratory culture studies, carbon-normalized and cell-normalized lipid contents provide broadly similar responses to environmental parameter changes in most cases, but there are exceptions (Ding et al., 2019; this study). However, cell-normalization is difficult for sediment reconstruction, as phytoplankton cell counting is often not quantitative (Piepho et al., 2010; Ahmed and Schenk, 2017). In the present study, we focus on the implications of our findings based on particulate organic carbon (POC)-normalized contents of lipid biomarkers. For example, our study revealed an overall $20 \%$ decrease in carbon-normalized contents of brassicasterol / epibrassicasterol in Rhodomonas sp. and E. huxleyi in oceanrelated global change scenarios but not in the diatom $P$. tricornutum. Because smaller ranges are expected in temperature, $\mathrm{N}: \mathrm{P}$ supply ratio and $p \mathrm{CO}_{2}$ in individual locations over time, our results provide additional support for the applicability of using sterols in paleoproductivity reconstruction, especially in diatom-dominated areas. Furthermore, we observed that $\mathrm{C}_{37} / \mathrm{C}_{38}$ alkenone ratios varied significantly with the changes in temperature, $\mathrm{N}$ : $\mathrm{P}$ supply ratios and $p \mathrm{CO}_{2}$, indicating that, besides temperature, other environmental factors may also significantly influence $\mathrm{C}_{37} / \mathrm{C}_{38}$ alkenone ratios. In contrast, $\mathrm{C}_{38} \mathrm{Et} / \mathrm{Me}$ ratios in our study responded significantly only to temperature changes. These results denote the importance to consider the effects of multiple environmental factors on $\mathrm{C}_{37} / \mathrm{C}_{38}$ alkenone ratios, and they further underline the importance of temperature in geological application of alkenone ratios.

\section{Conclusions}

The responses of sterols, alkenones and FAs to projected future scenario changes in temperature, $\mathrm{N}$ : $\mathrm{P}$ supply ratios and $p \mathrm{CO}_{2}$ were experimentally examined in three phytoplank- ton species. Our results reveal that $\mathrm{N}$ and $\mathrm{P}$ deficiency had a stronger effect on per-cell contents of the three lipid biomarkers, while the effects of warming and high $p \mathrm{CO}_{2}$ were relatively moderate. We also show that $\mathrm{P}$ deficiency caused an increase but $\mathrm{N}$ deficiency led to a decrease in per-cell contents of lipids in most cases. Our results provide important new evidence to previous transcriptomic and metabolomic studies, which showed that key metabolites were up-regulated in response to $\mathrm{P}$ deficiency, while most central metabolites were down-regulated in response to $\mathrm{N}$ deficiency. Such transcriptomic and metabolomic rearrangements are linked to the regulation of lipid biosynthesis-related genes (Read et al., 2013; Wördenweber et al., 2018). Future studies are suggested to consider the influence of these, and other environmental changes on the composition of major and minor sterols, alkenoates and other energy storage molecules such as triacylglycerols, e.g., whether varying environmental conditions influence C-24 alkylation in sterols.

Our study demonstrates that, under future ocean scenarios, the overall carbon-normalized contents of brassicasterol / epi-brassicasterol and PUFAs decreased in most cases in the three algal species; however, nonsignificant changes were also observed in brassicasterol / epi-brassicasterol and alkenones and a significant increase was found in PUFAs in one of the three species (Rhodomonas sp.). This result highlights that a diverse allocation of carbon would potentially occur between lipid biomarkers and between phytoplankton taxa when they acclimate to large fluctuations in environmental conditions. Such variations in the contents of essential lipids (sterols and PUFAs) and in carbon allocation strategies may influence the structures and functions of food webs and the future ocean ecosystems.

Data availability. Data supporting the conclusions is publicly available at https://doi.org/10.5281/zenodo.4163040.

Supplement. The supplement related to this article is available online at: https://doi.org/10.5194/bg-17-6287-2020-supplement.

Author contributions. RB, SMHIR, US and MZ designed the experiments. RB carried out the experiments, with the assistance of HZ. RB prepared the article with contributions from all co-authors.

Competing interests. The authors declare that they have no conflict of interest.

Acknowledgements. We are grateful to Thomas Hansen, Cordula Meyer, Bente Gardeler, Petra Schulz, Li Li, Yang Ding, Guie Jin and Yu Zhan for technical assistance. We thank Birte Matthiessen, Renate Ebbinhaus, and Lena Eggers for providing the E. huxleyi strain; Lea Kraienhemke, Dorthe Ozod-Seradj, 
Carolin Paul, Si Li, Xupeng Chi, Yong Zhang, and Bei Su for helping with the experiments; and Philipp Neitzschel, Kastriot Qelaj, and Jens Wernhöner for helping with DIC measurements. We also thank Julian Sachs and Weiguo Liu for their comments on alkenone identification. We are particularly grateful to Julian Sachs for his insightful suggestions on earlier drafts of this article and to the two anonymous reviewers whose comments greatly improved this article. This is MCTL (Key Laboratory of Marine Chemistry Theory and Technology) contribution 209.

Financial support. This research has been supported by the National Natural Science Foundation of China (grant nos. 41630966, 41876118 and U1706219), the Youth Talent Support Program of the Laboratory for Marine Ecology and Environmental Science, the Pilot National Laboratory for Marine Science and Technology (Qingdao) (grant no. LMEES-YTSP-2018-02-01), the Fundamental Research Funds for the Central Universities (grant no. 201713027), the "111" Project (grant no. B13030), and GEOMAR HelmholtzZentrum für Ozeanforschung Kiel.

Review statement. This paper was edited by Carolin Löscher and reviewed by two anonymous referees.

\section{References}

Abida, H., Dolch, L.-J., Mei, C., Villanova, V., Conte, M., Block, M. A., Finazzi, G., Bastien, O., Tirichine, L., Bowler, C., Rebeille, F., Petroutsos, D., Jouhet, J., and Marechal, E.: Membrane glycerolipid remodeling triggered by nitrogen and phosphorus starvation in Phaeodactylum tricornutum, Plant Physiol., 167, 118136, https://doi.org/10.1104/pp.114.252395, 2015.

Ahmed, F. and Schenk, P. M.: UV-C radiation increases sterol production in the microalga Pavlova lutheri, Phytochemistry, 139, 25-32, https://doi.org/10.1016/j.phytochem.2017.04.002, 2017.

Amin, R. M., Koski, M., Bamstedt, U., and Vidoudez, C.: Strainrelated physiological and behavioral effects of Skeletonema marinoi on three common planktonic copepods, Mar. Biol., 158, 1965-1980, https://doi.org/10.1007/s00227-011-1706-7, 2011.

Arndt, C. and Sommer, U.: Effect of algal species and concentration on development and fatty acid composition of two harpacticoid copepods, Tisbe sp. and Tachidius discipes, and a discussion about their suitability for marine fish larvae, Aquac. Nutr., 20, 44-59, https://doi.org/10.1111/anu.12051, 2014.

Arts, M. T., Brett, M. T., and Kainz, M.: Introduction, in: Lipids in aquatic ecosystems, edited by: Arts, M. T., Brett, M. T., and Kainz, M., Springer, Heidelberg, Germany, xv-xx, https://doi.org/10.1007/978-0-387-89366-2, 2009.

Bakku, R. K., Araie, H., Hanawa, Y., Shiraiwa, Y., and Suzuki, I.: Changes in the accumulation of alkenones and lipids under nitrogen limitation and its relation to other energy storage metabolites in the haptophyte alga Emiliania huxleyi CCMP 2090, J. Appl. Phycol., 30, 23-36, https://doi.org/10.1007/s10811-017-1163-x, 2018.

Ballantine, J. A., Lavis, A., and Morris, R. J.: Sterols of the phytoplankton - effects of illumination and growth stage,
Phytochemistry, 18, 1459-1466, https://doi.org/10.1016/S00319422(00)98475-9, 1979.

Bell, M. V. and Pond, D.: Lipid composition during growth of motile and coccolith forms of Emiliania huxleyi, Phytochemistry, 41, 465-471, https://doi.org/10.1016/0031-9422(95)00663-x, 1996.

Bermúdez, R., Feng, Y., Roleda, M. Y., Tatters, A. O., Hutchins, D. A., Larsen, T., Boyd, P. W., Hurd, C. L., Riebesell, U., and Winder, M.: Long-term conditioning to elevated $p \mathrm{CO}_{2}$ and warming influences the fatty and amino acid composition of the diatom Cylindrotheca fusiformis, Plos One, 10, e0123945, https://doi.org/10.1371/journal.pone.0123945, 2015.

Bi, R., Arndt, C., and Sommer, U.: Stoichiometric responses of phytoplankton species to the interactive effect of nutrient supply ratios and growth rates, J. Phycol., 48, 539-549, https://doi.org/10.1111/j.1529-8817.2012.01163.x, 2012.

Bi, R., Arndt, C., and Sommer, U.: Linking elements to biochemicals: effects of nutrient supply ratios and growth rates on fatty acid composition of phytoplankton species, J. Phycol., 50, 117130, https://doi.org/10.1111/jpy.12140, 2014.

Bi, R., Ismar, S. M. H., Sommer, U., and Zhao, M.: Environmental dependence of the correlations between stoichiometric and fatty acid-based indicators of phytoplankton nutritional quality, Limnol. Oceanogr., 62, 334-347, https://doi.org/10.1002/lno.10429, 2017.

Bi, R., Ismar, S. M. H., Sommer, U., and Zhao, M.: Simultaneous shifts in elemental stoichiometry and fatty acids of Emiliania huxleyi in response to environmental changes, Biogeosciences, 15, 1029-1045, https://doi.org/10.5194/bg-15-1029-2018, 2018.

Bi, R. and Sommer, U.: Food quantity and quality interactions at phytoplankton-zooplankton interface: chemical and reproductive responses in a calanoid copepod, Front. Mar. Sci., 7, 274, https://doi.org/10.3389/fmars.2020.00274, 2020.

Bolker, B. M., Brooks, M. E., Clark, C. J., Geange, S. W., Poulsen, J. R., Stevens, M. H. H., and White, J.-S. S.: Generalized linear mixed models: a practical guide for ecology and evolution, Trends Ecol. Evol., 24, 127-135, https://doi.org/10.1016/j.tree.2008.10.008, 2009.

Bonnet, S., Guieu, C., Bruyant, F., Prášil, O., Van Wambeke, F., Raimbault, P., Moutin, T., Grob, C., Gorbunov, M. Y., Zehr, J. P., Masquelier, S. M., Garczarek, L., and Claustre, H.: Nutrient limitation of primary productivity in the Southeast Pacific (BIOSOPE cruise), Biogeosciences, 5, 215-225, https://doi.org/10.5194/bg5-215-2008, 2008.

Boyce, D. G., Lewis, M. R., and Worm, B.: Global phytoplankton decline over the past century, Nature, 466, 591-596, https://doi.org/10.1038/nature09268, 2010.

Braeckman, U., Janssen, F., Lavik, G., Elvert, M., Marchant, H., Buckner, C., Bienhold, C., and Wenzhöfer, F.: Carbon and nitrogen turnover in the Arctic deep sea: in situ benthic community response to diatom and coccolithophorid phytodetritus, Biogeosciences, 15, 6537-6557, https://doi.org/10.5194/bg-156537-2018, 2018.

Brassell, S. C., Eglinton, G., Marlowe, I. T., Pflaumann, U., and Sarnthein, M.: Molecular stratigraphy: a new tool for climatic assessment, Nature, 320, 129-133, https://doi.org/10.1038/320129a0, 1986.

Brassell, S. C., Dumitrescu, M., and Party, O. D. P. L. S. S.: Recognition of alkenones in a lower Aptian porcellanite 
from the west-central Pacific, Org. Geochem., 35, 181-188, https://doi.org/10.1016/j.orggeochem.2003.09.003, 2004.

Brassell, S. C.: Climatic influences on the Paleogene evolution of alkenones, Paleoceanography, 29, 255-272, https://doi.org/10.1002/2013pa002576, 2014.

Breteler, W., Schogt, N., and Rampen, S.: Effect of diatom nutrient limitation on copepod development: role of essential lipids, Mar. Ecol. Prog. Ser., 291, 125-133, https://doi.org/10.3354/meps291125, 2005.

Brett, M. and Müller-Navarra, D. C.: The role of highly unsaturated fatty acids in aquatic foodweb processes, Freshw. Biol., 38, 483499, https://doi.org/10.1046/j.1365-2427.1997.00220.x, 1997.

Brocks, J. J., Jarrett, A. J. M., Sirantoine, E., Hallmann, C., Hoshino, Y., and Liyanage, T.: The rise of algae in Cryogenian oceans and the emergence of animals, Nature, 548, 578-581, https://doi.org/10.1038/nature23457, 2017.

Chen, M., Bi, R., Chen, X., Ding, Y., Zhang, H., Li, L., and Zhao, M.: Stoichiometric and sterol responses of dinoflagellates to changes in temperature, nutrient supply and growth phase, Algal Res., 42, 101609, https://doi.org/10.1016/j.algal.2019.101609, 2019.

Chen, X., Wakeham, S. G., and Fisher, N. S.: Influence of iron on fatty acid and sterol composition of marine phytoplankton and copepod consumers, Limnol. Oceanogr., 56, 716-724, https://doi.org/10.4319/lo.2011.56.2.0716, 2011.

Christie, W. W.: Gas Chromatography and Lipids, The Oily Press, Bridgwater, Somerset, UK, 1989.

Conte, M. H., Volkman, J. K., and Eglinton, G.: Lipid biomarkers of the Haptophyta, in: The Haptophyte Algae, edited by: Green, J. C. and Leadbeater, B. S. C., Clarendon Press, Oxford, UK, 351-377, 1994.

Conte, M. H., Thompson, A., Eglinton, G., and Green, J. C.: Lipid biomarker diversity in the coccolithophorid Emiliania huxleyi (Prymnesiophyceae) and the related species Gephyrocapsa oceanica, J. Phycol., 31, 272-282, https://doi.org/10.1111/j.0022-3646.1995.00272.x, 1995.

Conte, M. H., Thompson, A., Lesley, D., and Harris, R. P.: Genetic and physiological influences on the alkenone/alkenoate versus growth temperature relationship in Emiliania huxleyi and Gephyrocapsa Oceanic, Geochim. Cosmochim. Ac., 62, 51-68, https://doi.org/10.1016/S0016-7037(97)00327-X, 1998.

Cvejić, J. H. and Rohmer, M.: $\mathrm{CO}_{2}$ as main carbon source for isoprenoid biosynthesis via the mevalonate-independent methylerythritol 4-phosphate route in the marine diatoms Phaeodactylum tricornutum and Nitzschia ovalis, Phytochemistry, 53, 21-28, https://doi.org/10.1016/s0031-9422(99)00465-3, 2000.

Dalsgaard, J., St. John, M., Kattner, G., Müller-Navarra, D., and Hagen, W.: Fatty acid trophic markers in the pelagic marine environment, Adv. Mar. Biol., 46, 225-340, https://doi.org/10.1016/S0065-2881(03)46005-7, 2003.

de Leeuw, J. W., van der Meer, M. T. J., Rijpstra, W. I. C., and Schenck, P. A.: On the occurrence and structural identification of long chain ketones and hydrocarbons in sediments, in: Advances in Organic Geochemistry, edited by: Douglas, A. G. and Maxwell, J. R., Pergamon Press, Oxford, UK, 211-217, https://doi.org/10.1016/0079-1946(79)90105-8, 1980.

De Martino, A., Meichenin, A., Shi, J., Pan, K., and Bowler, C.: Genetic and phenotypic characterization of Phaeodactylum tricor- nutum (Bacillariophyceae) accessions, J. Phycol., 43, 992-1009, https://doi.org/10.1111/j.1529-8817.2007.00384.x, 2007.

DeVries, T., Holzer, M., and Primeau, F.: Recent increase in oceanic carbon uptake driven by weaker upper-ocean overturning, Nature, 542, 215-218, https://doi.org/10.1038/nature21068, 2017.

Dickson, A. and Millero, F.: A comparison of the equilibrium constants for the dissociations of carbonic acid in seawater media, Deep-Sea Res., 34, 1733-1741, https://doi.org/10.1016/01980149(87)90021-5, 1987.

Ding, Y., Bi, R., Sachs, J. P., Chen, X., Zhang, H. L., Li, L., and Zhao, M.: Lipid biomarker production by marine phytoplankton under different nutrient and temperature regimes, Org. Geochem., 131, 34-49, https://doi.org/10.1016/j.orggeochem.2019.01.008, 2019.

Doney, S. C., Ruckelshaus, M., Duffy, J. E., Barry, J. P., Chan, F., English, C. A., Galindo, H. M., Grebmeier, J. M., Hollowed, A. B., Knowlton, N., Polovina, J., Rabalais, N. N., Sydeman, W. J., and Talley, L. D.: Climate change impacts on marine ecosystems, Annu. Rev. Mar. Sci., 4, 11-37, https://doi.org/10.1146/annurevmarine-041911-111611, 2012.

Dunstan, G. A., Brown, M. R., and Volkman, J. K.: Cryptophyceae and rhodophyceae; chemotaxonomy, phylogeny, and application, Phytochemistry, 66, 2557-2570, https://doi.org/10.1016/j.phytochem.2005.08.015, 2005.

du Pontavice, H., Gascuel, D., Reygondeau, G., Maureaud, A., and Cheung, W. W. L.: Climate change undermines the global functioning of marine food webs, Glob. Change Biol., 26, 13061318, https://doi.org/10.1111/gcb.14944, 2020.

Eltgroth, M. L., Watwood, R. L., and Wolfe, G. V.: Production and cellular localization of neutral long-chain lipids in the haptophyte algae Isochrysis galbana and Emiliania huxleyi, J. Phycol., 41, 1000-1009, https://doi.org/10.1111/j.15298817.2005.00128.x, 2005.

Epstein, B. L., D’Hondt, S., Quinn, J. G., Zhang, J. P., and Hargraves, P. E.: An effect of dissolved nutrient concentrations on alkenone-based temperature estimates, Paleoceanography, 13, 122-126, https://doi.org/10.1029/97pa03358, 1998.

Epstein, B. L., D'Hondt, S., and Hargraves, P. E.: The possible metabolic role of $\mathrm{C}_{37}$ alkenones in Emiliania huxleyi, Org. Geochem., 32, 867-875, https://doi.org/10.1016/s01466380(01)00026-2, 2001.

Fabris, M., Matthijs, M., Rombauts, S., Vyverman, W., Goossens, A., and Baart, G. J. E.: The metabolic blueprint of Phaeodactylum tricornutum reveals a eukaryotic EntnerDoudoroff glycolytic pathway, Plant J., 70, 1004-1014, https://doi.org/10.1111/j.1365-313X.2012.04941.x, 2012.

Fabris, M., Matthijs, M., Carbonelle, S., Moses, T., Pollier, J., Dasseville, R., Baart, G. J. E., Vyverman, W., and Goossens, A.: Tracking the sterol biosynthesis pathway of the diatom Phaeodactylum tricornutum, New Phytol., 204, 521-535, https://doi.org/10.1111/nph.12917, 2014.

Falkowski, P.: Life's engines: How microbes made Earth habitable, Princeton University Press, Princeton, 205 pp., 2015.

Falkowski, P. and Freeman, K. H.: Volume Editors' Introduction, in: Treatise on Geochemistry, edited by: Holland, $\mathrm{H}$. D. and Turekian, K. K., Elsevier Science, Oxford, UK, 416, https://doi.org/10.1016/B978-0-08-095975-7.09981-2, 2014. 
Falkowski, P. G. and Oliver, M. J.: Mix and match: how climate selects phytoplankton, Nat. Rev. Micro., 5, 813-819, https://doi.org/10.1038/nrmicro1792, 2007.

Ford, R. C. and Barber, J.: Incorporation of sterol into chloroplast thylakoid membranes and its effect on fluidity and function, Planta, 158, 35-41, https://doi.org/10.1007/bf00395400, 1983.

Galloway, A. W. E. and Winder, M.: Partitioning the relative importance of phylogeny and environmental conditions on phytoplankton fatty acids, Plos One, 10, e0130053, https://doi.org/10.1371/journal.pone.0130053, 2015.

Gladu, P. K., Patterson, G. W., Wikfors, G. H., Chitwood, D. J., and Lusby, W. R.: The occurrence of brassicasterol and epibrassicasterol in the Chromophycota, Comp. Biochem. Phys. B, 97, 491-494, https://doi.org/10.1016/0305-0491(90)90149-n, 1990.

Gladu, P. K., Patterson, G. W., Wikfors, G. H., Chitwood, D. J., and Lusby, W. R.: Sterols of some diatoms, Phytochemistry, 30, 2301-2303, https://doi.org/10.1016/0031-9422(91)83634-w, 1991.

Goad, L. J., Holz Jr., G. G., and Heach, D. H.: Identification of (24S)-24-methylcholesta-5,22-dien-3 $\beta$-ol as the major sterol of a marine cryptophyte and a marine prymnesiophyte, Phytochemistry, 22, 475-476, https://doi.org/10.1016/00319422(83)83028-3, 1983.

Gordillo, F. J. L., Goutx, M., Figueroa, F. L., and Niell, F. X.: Effects of light intensity, $\mathrm{CO}_{2}$ and nitrogen supply on lipid class composition of Dunaliella viridis, J. Appl. Phycol., 10, 135-144, https://doi.org/10.1023/a:1008067022973, 1998.

Gordillo, F. J. L., Jimenez, C., Goutx, M., and Niell, X.: Effects of $\mathrm{CO}_{2}$ and nitrogen supply on the biochemical composition of Ulva rigida with especial emphasis on lipid class analysis, J. Plant Physiol., 158, 367-373, https://doi.org/10.1078/01761617-00209, 2001

Gruber, N.: Warming up, turning sour, losing breath: ocean biogeochemistry under global change, Philos. T. Roy. Soc. A, 369, 1980-1996, https://doi.org/10.1098/rsta.2011.0003, 2011.

Guillard, R. R. L.: Culture of Phytoplankton for Feeding Marine Invertebrates, in: Culture of Marine Invertebrate Animals, edited by: Smith, W. L. and Chanley, M. H., Springer, Boston, MA, USA, 29-60, https://doi.org/10.1007/978-1-46158714-9_3, 1975.

Guschina, I. A. and Harwood, J. L.: Algal lipids and effect of the environment on their biochemistry, in: Lipids in Aquatic Ecosystems, edited by: Arts, M. T., Brett, M. T., and Kainz, M. J., Springer, Heidelberg, Germany, 1-24, https://doi.org/10.1007/978-0-387-89366-2_1, 2009.

Halsey, K. H. and Jones, B. M.: Phytoplankton strategies for photosynthetic energy allocation, Annu. Rev. Mar. Sci., 7, 265-297, https://doi.org/10.1146/annurev-marine-010814-015813, 2015.

Hansen, T., Gardeler, B., and Matthiessen, B.: Technical Note: Precise quantitative measurements of total dissolved inorganic carbon from small amounts of seawater using a gas chromatographic system, Biogeosciences, 10, 6601-6608, https://doi.org/10.5194/bg-10-6601-2013, 2013.

Hansson, I.: A new set of acidity constants for carbonic acid and boric acid in seawater, Deep-Sea Res., 20, 661-678, https://doi.org/10.1016/0011-7471(73)90100-9, 1973.

Harris, R. P.: Zooplankton grazing on the coccolithophore Emiliania huxleyi and its role in inorganic carbon flux, Mar. Biol., 119, 431-439, https://doi.org/10.1007/BF00347540, 1994.
Hartmann, M. A.: Plant sterols and the membrane environment, Trends Plant Sci., 3, 170-175, https://doi.org/10.1016/s13601385(98)01233-3, 1998.

Hassett, R. P.: Supplementation of a diatom diet with cholesterol can enhance copepod egg-production rates, Limnol. Oceanogr. 49, 488-494, https://doi.org/10.4319/lo.2004.49.2.0488, 2004.

Herbert, T. D., Lawrence, K. T., Tzanova, A., Peterson, L. C., Caballero-Gill, R., and Kelly, C. S.: Late Miocene global cooling and the rise of modern ecosystems, Nat. Geosci., 9, 843-847, https://doi.org/10.1038/ngeo2813, 2016.

Hiebenthal, C., Philipp, E. E. R., Eisenhauer, A., and Wahl, M.: Effects of seawater $p \mathrm{CO}_{2}$ and temperature on shell growth, shell stability, condition and cellular stress of Western Baltic Sea Mytilus edulis (L.) and Arctica islandica (L.), Mar. Biol., 160, 2073-2087, https://doi.org/10.1007/s00227-012-2080-9, 2013.

Highfield, J. M., Eloire, D., Conway, D. V. P., Lindeque, P. K., Attrill, M. J., and Somerfield, P. J.: Seasonal dynamics of meroplankton assemblages at station L4, J. Plankton Res., 32, 681691, 10.1093/plankt/fbp139, 2010.

Hixson, S. M. and Arts, M. T.: Climate warming is predicted to reduce omega-3, long-chain, polyunsaturated fatty acid production in phytoplankton, Glob. Change Biol., 22, 2744-2755, https://doi.org/10.1111/gcb.13295, 2016.

Hoegh-Guldberg, O. and Bruno, J. F.: The impact of climate change on the world's marine ecosystems, Science, 328, 1523-1528, https://doi.org/10.1126/science.1189930, 2010.

Hofmann, M. and Schellnhuber, H.-J.: Oceanic acidification affects marine carbon pump and triggers extended marine oxygen holes, Proc. Natl. Acad. Sci. USA., 106, 3017-3022, https://doi.org/10.1073/pnas.0813384106, 2009.

IPCC: Climate change 2014: Synthesis report. Contribution of working groups I, II and III to the fifth assessment report of the intergovernmental panel on climate change, Geneva, Switzerland, Intergovernmental Panel on Climate Change (IPCC), 2014.

Ismar, S. M. H., Hansen, T., and Sommer, U.: Effect of food concentration and type of diet on Acartia survival and naupliar development, Mar. Biol., 154, 335-343, https://doi.org/10.1007/s00227008-0928-9, 2008.

Jónasdóttir, S. H., Visser, A. W., and Jespersen, C.: Assessing the role of food quality in the production and hatching of Temora longicornis eggs, Mar. Ecol. Prog. Ser., 382, 139-150, https://doi.org/10.3354/meps07985, 2009.

Jonkers, L., Hillebrand, H., and Kucera, M.: Global change drives modern plankton communities away from the pre-industrial state, Nature, 570, 372-375, https://doi.org/10.1038/s41586019-1230-3, 2019.

Kassambara, A. and Mundt, F.: factoextra: Extract and visualize the results of multivariate data analyses, available at: http://www. sthda.com/english/rpkgs/factoextra, last access: 16 September 2019.

Kelly, J. R. and Scheibling, R. E.: Fatty acids as dietary tracers in benthic food webs, Mar. Ecol. Prog. Ser., 446, 1-22, https://doi.org/10.3354/meps09559, 2012.

Kitamura, E., Kotajima, T., Sawada, K., Suzuki, I., and Shiraiwa, Y.: Cold-induced metabolic conversion of haptophyte di- to triunsaturated $\mathrm{C}_{37}$ alkenones used as palaeothermometer molecules, Sci. Rep.-UK, 8, 2196, https://doi.org/10.1038/s41598-018-20741-2, 2018. 
Klein-Breteler, W. C. M., Schogt, N., and Rampen, S.: Effect of diatom nutrient limitation on copepod development: role of essential lipids, Mar. Ecol. Prog. Ser., 291, 125-133, https://doi.org/10.3354/meps291125, 2005.

Kortsch, S., Primicerio, R., Fossheim, M., Dolgov, A. V., and Aschan, M.: Climate change alters the structure of arctic marine food webs due to poleward shifts of boreal generalists, P. Roy. Soc. B-Biol. Sci., 282, 31-39, https://doi.org/10.1098/rspb.2015.1546, 2015.

Kumar, V., Sinha, A. K., Romano, N., Allen, K. M., Bowman, B. A., Thompson, K. R., and Tidwell, J. H.: Metabolism and nutritive role of cholesterol in the growth, gonadal development, and reproduction of crustaceans, Rev. Fish. Sci. Aquac., 26, 254-273, https://doi.org/10.1080/23308249.2018.1429384, 2018.

Lampert, W. and Sommer, U.: Limnoecology: The ecology of lakes and streams, 2nd ed., Oxford University Press, Oxford, UK, 2007

Le, S., Josse, J., and Husson, F.: FactoMineR: An R package for multivariate analysis, J. Stat. Softw., 25, 1-18, https://doi.org/10.18637/jss.v025.i01, 2008.

Lopez, J. F. and Grimalt, J. O.: Reassessment of the structural composition of the alkenone distributions in natural environments using an improved method for double bond location based on GCMS analysis of cyclopropylimines, J. Am. Soc. Mass Spectr., 17, 710-720, https://doi.org/10.1016/j.jasms.2006.01.015, 2006.

Lotze, H. K., Tittensor, D. P., Bryndum-Buchholz, A., Eddy, T. D., Cheung, W. W. L., Galbraith, E. D., Barange, M., Barrier, N., Bianchi, D., Blanchard, J. L., Bopp, L., Buchner, M., Bulman, C. M., Carozza, D. A., Christensen, V., Coll, M., Dunne, J. P., Fulton, E. A., Jennings, S., Jones, M. C., Mackinson, S., Maury, O., Niiranen, S., Oliveros-Ramos, R., Roy, T., Fernandes, J. A., Schewe, J., Shin, Y.-J., Silva, T. A. M., Steenbeek, J., Stock, C. A., Verley, P., Volkholz, J., Walker, N. D., and Worm, B.: Global ensemble projections reveal trophic amplification of ocean biomass declines with climate change, Proc. Natl. Acad. Sci. USA., 116, 12907-12912, https://doi.org/10.1073/pnas.1900194116, 2019.

Lynn, S. G., Kilham, S. S., Kreeger, D. A., and Interlandi, S. J.: Effect of nutrient availability on the biochemical and elemental stoichiometry in the freshwater diatom Stephanodiscus minutulus (Bacillariophyceae), J. Phycol., 36, 510-522, https://doi.org/10.1046/j.1529-8817.2000.98251.x, 2000.

Marlowe, I. T., Green, J. C., Neal, A. C., Brassell, S. C., Eglinton, G., and Course, P. A.: Long chain $\left(n-\mathrm{C}_{37}-\mathrm{C}_{39}\right)$ alkenones in the Prymnesiophyceae. Distribution of alkenones and other lipids and their taxonomic significance, Brit. Phycol. J., 19, 203-216, https://doi.org/10.1080/00071618400650221, 1984.

Martin-Creuzburg, D. and Merkel, P.: Sterols of freshwater microalgae: potential implications for zooplankton nutrition, J. Plankton Res., 38, 865-877, https://doi.org/10.1093/plankt/fbw034, 2016.

Martin-Creuzburg, D. and von Elert, E.: Good food versus bad food: the role of sterols and polyunsaturated fatty acids in determining growth and reproduction of Daphnia magna, Aquat. Ecol., 43, 943-950, https://doi.org/10.1007/s10452-009-9239-6, 2009a.

Martin-Creuzburg, D. and von Elert, E.: Ecological significance of sterols in aquatic food webs, in: Lipids in Aquatic Ecosystems, edited by: Arts, M. T., Brett, M. T., and Kainz, M., Springer, Heidelberg, Germany, 43-64, https://doi.org/10.1007/978-0-38789366-2_3, 2009b.
Martin-Creuzburg, D., Wacker, A., and von Elert, E.: Life history consequences of sterol availability in the aquatic keystone species Daphnia, Oecologia, 144, 362-372, https://doi.org/10.1007/s00442-005-0090-8, 2005.

Martin-Creuzburg, D., Sperfeld, E., and Wacker, A.: Colimitation of a freshwater herbivore by sterols and polyunsaturated fatty acids, P. Roy. Soc. B-Biol. Sci., 276, 1805-1814, https://doi.org/10.1098/rspb.2008.1540, 2009.

Martin-Creuzburg, D., Oexle, S., and Wacker, A.: Thresholds for sterol-limited growth of Daphnia magna: A comparative approach using 10 different sterols, J. Chem. Ecol., 40, 1039-1050, https://doi.org/10.1007/s10886-014-0486-1, 2014.

Marzetz, V., Koussoroplis, A.-M., Martin-Creuzburg, D., Striebel, M., and Wacker, A.: Linking primary producer diversity and food quality effects on herbivores: A biochemical perspective, Sci. Rep.-UK, 7, 11035, https://doi.org/10.1038/s41598-017-111833, 2017.

Mausz, M. A. and Pohnert, G.: Phenotypic diversity of diploid and haploid Emiliania huxleyi cells and of cells in different growth phases revealed by comparative metabolomics, J. Plant Physiol., 172, 137-148, https://doi.org/10.1016/j.jplph.2014.05.014, 2015.

Maxwell, J. R., Mackenzie, A. S., and Volkman, J. K.: Configuration at C-24 in steranes and sterols, Nature, 286, 694-697, https://doi.org/10.1038/286694a0, 1980.

Mehrbach, C., Culberson, C., Hawley, J., and Pytkowicz, R.: Measurement of the apparent dissociation constants of carbonic acid in seawater at atmospheric pressure, Limnol. Oceanogr, 18, $897-$ 907, https://doi.org/10.4319/lo.1973.18.6.0897, 1973.

Moore, C. M., Mills, M. M., Arrigo, K. R., Berman-Frank, I., Bopp, L., Boyd, P. W., Galbraith, E. D., Geider, R. J., Guieu, C., Jaccard, S. L., Jickells, T. D., La Roche, J., Lenton, T. M., Mahowald, N. M., Maranon, E., Marinov, I., Moore, J. K., Nakatsuka, T., Oschlies, A., Saito, M. A., Thingstad, T. F., Tsuda, A., and Ulloa, O.: Processes and patterns of oceanic nutrient limitation, Nat. Geosci., 6, 701-710, https://doi.org/10.1038/ngeo1765, 2013.

Moore, J. K., Fu, W., Primeau, F., Britten, G. L., Lindsay, K., Long, M., Doney, S. C., Mahowald, N., Hoffman, F., and Randerson, J. T.: Sustained climate warming drives declining marine biological productivity, Science, 359, 1139-1142, https://doi.org/10.1126/science.aao6379, 2018.

Müller-Navarra, D.: Food web paradigms: The biochemical view on trophic interactions, Internat. Rev. Hydrobiol., 93, 489-505, https://doi.org/10.1002/iroh.200711046, 2008.

Müller-Navarra, D. C., Brett, M. T., Liston, A. M., and Goldman, C. R.: A highly unsaturated fatty acid predicts carbon transfer between primary producers and consumers, Nature, 403, 74-77, https://doi.org/10.1038/47469, 2000.

Nakamura, H., Sawada, K., Araie, H., Suzuki, I., and Shiraiwa, Y.: Long chain alkenes, alkenones and alkenoates produced by the haptophyte alga Chrysotila lamellosa CCMP1307 isolated from a salt marsh, Org. Geochem., 66, 90-97, https://doi.org/10.1016/j.orggeochem.2013.11.007, 2014.

Nejstgaard, J. C., Gismervik, I., and Solberg, P. T.: Feeding and reproduction by Calanus finmarchicus, and microzooplankton grazing during mesocosm blooms of diatoms and the coccolithophore Emiliania huxleyi, Mar. Ecol. Prog. Ser., 147, 197217, https://doi.org/10.3354/meps147197, 1997. 
Orcutt, D. M. and Patterson, G. W.: Sterol, fatty acid and elemental composition of diatoms grown in chemically defined media, Comp. Biochem. Phys. B, 50, 579-583, https://doi.org/10.1016/0305-0491(75)90093-0, 1975.

Palmucci, M., Ratti, S., and Giordano, M.: Ecological and evolutionary implications of carbon allocation in marine phytoplankton as a function of nitrogen availability: a fourier transform infrared spectroscopy approach, J. Phycol., 47, 313-323, https://doi.org/10.1111/j.1529-8817.2011.00963.x, 2011.

Pan, H. and Sun, M.-Y.: Variations of alkenone based paleotemperature index $\left(U_{37}^{K^{\prime}}\right)$ during Emiliania huxleyi cell growth, respiration (auto-metabolism) and microbial degradation, Org. Geochem., 42, 678-687, https://doi.org/10.1016/j.orggeochem.2011.03.024, 2011.

Peñuelas, J., Sardans, J., Rivas-Ubach, A., and Janssens, I. A.: The human-induced imbalance between $\mathrm{C}, \mathrm{N}$ and $\mathrm{P}$ in Earth's life system, Glob. Change Biol., 18, 3-6, https://doi.org/10.1111/j.13652486.2011.02568.x, 2012.

Piepho, M., Martin-Creuzburg, D., and Wacker, A.: Simultaneous effects of light intensity and phosphorus supply on the sterol content of phytoplankton, Plos One, 5, e15828, https://doi.org/10.1371/journal.pone.0015828, 2010.

Piepho, M., Martin-Creuzburg, D., and Wacker, A.: Phytoplankton sterol contents vary with temperature, phosphorus and silicate supply: a study on three freshwater species, Eur. J. Phycol., 47, 138-145, https://doi.org/10.1080/09670262.2012.665484, 2012.

Pierrot, D., Lewis, E., and Wallace, D.: MS Excel program developed for $\mathrm{CO}_{2}$ system calculations: ORNL/CDIAC-105a, Carbon Dioxide Information Analysis Centre, Oak Ridge National Laboratory, US Department of Energy, Oak Ridge, TN, 2006.

Prahl, F. G. and Wakeham, S. G.: Calibration of unsaturation patterns in long-chain ketone compositions for palaeotemperature assessment, Nature, 330, 367-369, https://doi.org/10.1038/330367a0, 1987.

Prahl, F. G., Muehlhausen, L. A., and Zahnle, D. L.: Further evaluation of long-chain alkenones as indicators of paleoceanographic conditions, Geochim. Cosmochim. Ac., 52, 2303-2310, https://doi.org/10.1016/0016-7037(88)90132-9, 1988.

Prahl, F. G., Wolfe, G. V., and Sparrow, M. A.: Physiological impacts on alkenone paleothermometry, Paleoceanography, 18, 1025, https://doi.org/10.1029/2002pa000803, 2003.

Provasoli, L.: Growing marine seaweeds., in: Proc. 4th Internatl. Seaweed Symp., edited by: De Virville, A. D. and Feldmann, J., Pergamon Press, Oxford, UK, 9-17, 1963.

Rampen, S. W., Abbas, B. A., Schouten, S., and Damsté, J. S. S.: A comprehensive study of sterols in marine diatoms (Bacillariophyta): Implications for their use as tracers for diatom productivity, Limnol. Oceanogr., 55, 91-105, https://doi.org/10.4319/1o.2010.55.1.0091, 2010.

Read, B. A., Kegel, J., Klute, M. J., Kuo, A., Lefebvre, S. C., Maumus, F., Mayer, C., Miller, J., Monier, A., Salamov, A., Young, J., Aguilar, M., Claverie, J. M., Frickenhaus, S., Gonzalez, K., Herman, E. K., Lin, Y. C., Napier, J., Ogata, H., Sarno, A. F., Shmutz, J., Schroeder, D., de Vargas, C., Verret, F., von Dassow, P., Valentin, K., Van de Peer, Y., Wheeler, G., Allen, A. E., Bidle, K., Borodovsky, M., Bowler, C., Brownlee, C., Cock, J. M., Elias, M., Gladyshev, V. N., Groth, M., Guda, C., Hadaegh, A., Iglesias-Rodriguez, M. D., Jenkins, J., Jones, B. M., Lawson, T., Leese, F., Lindquist, E., Lobanov, A., Lomsadze, A.,
Malik, S. B., Marsh, M. E., Mackinder, L., Mock, T., MuellerRoeber, B., Pagarete, A., Parker, M., Probert, I., Quesneville, H., Raines, C., Rensing, S. A., Riano-Pachon, D. M., Richier, S., Rokitta, S., Shiraiwa, Y., Soanes, D. M., van der Giezen, M., Wahlund, T. M., Williams, B., Wilson, W., Wolfe, G., Wurch, L. L., Dacks, J. B., Delwiche, C. F., Dyhrman, S. T., Gloeckner, G., John, U., Richards, T., Worden, A. Z., Zhang, X. Y., and Grigoriev, I. V.: Pan genome of the phytoplankton Emiliania underpins its global distribution, Nature, 499, 209-213, https://doi.org/10.1038/nature12221, 2013.

Richardson, A. J. and Schoeman, D. S.: Climate impact on plankton ecosystems in the Northeast Atlantic, Science, 305, 1609-1612, https://doi.org/10.1126/science.1100958, 2004.

Riding, R.: The algal breath of life, Nature, 359, 13-14, https://doi.org/10.1038/359013a0, 1992.

Riebesell, U., Revill, A. T., Holdsworth, D. G., and Volkman, J. K.: The effects of varying $\mathrm{CO}_{2}$ concentration on lipid composition and carbon isotope fractionation in Emiliania huxleyi, Geochim. Cosmochim. Ac., 64, 4179-4192, https://doi.org/10.1016/s00167037(00)00474-9, 2000.

Rokitta, S. D., Von Dassow, P., Rost, B., and John, U.: Emiliania huxleyi endures N-limitation with an efficient metabolic budgeting and effective ATP synthesis, Bmc Genomics, 15, 1051, https://doi.org/10.1186/1471-2164-15-1051, 2014.

Rokitta, S. D., von Dassow, P., Rost, B., and John, U.: P- and Ndepletion trigger similar cellular responses to promote senescence in eukaryotic phytoplankton, Front. Mar. Sci., 3, 109, https://doi.org/10.3389/fmars.2016.00109, 2016.

Rontani, J.-F., Prahl, F. G., and Volkman, J. K.: Re-examination of the double bond positions in alkenones and derivatives: Biosynthetic implications, J. Phycol., 42, 800-813, https://doi.org/10.1111/j.1529-8817.2006.00251.x, 2006.

Rosell-Melé, A. and Prahl, F. G.: Seasonality of $U_{37}^{K^{\prime}} \quad$ temperature estimates as inferred from sediment trap data, Quaternary Sci. Rev., 72, 128-136, https://doi.org/10.1016/j.quascirev.2013.04.017, 2013.

Rossoll, D., Bermúdez, R., Hauss, H., Schulz, K. G., Riebesell, U., Sommer, U., and Winder, M.: Ocean acidification-induced food quality deterioration constrains trophic transfer, Plos One, 7, e34737, https://doi.org/10.1371/journal.pone.0034737, 2012.

Ruess, L. and Müller-Navarra, D. C.: Essential biomolecules in food webs, Front. Ecol. Evol., 7, 269, https://doi.org/10.3389/fevo.2019.00269, 2019.

Sachs, J. P. and Kawka, O. E.: The influence of growth rate on ${ }^{2} \mathrm{H} /{ }^{1} \mathrm{H}$ fractionation in continuous cultures of the coccolithophorid Emiliania huxleyi and the diatom Thalassiosira pseudonana, Plos One, 10, e0141643, https://doi.org/10.1371/journal.pone.0141643, 2015.

Sachs, J. P., Maloney, A. E., Gregersen, J., and Paschall, C.: Effect of salinity on ${ }^{2} \mathrm{H} /{ }^{1} \mathrm{H}$ fractionation in lipids from continuous cultures of the coccolithophorid Emiliania huxleyi, Geochim. Cosmochim. Ac., 189, 96-109, https://doi.org/10.1016/j.gca.2016.05.041, 2016.

Sawada, K. and Shiraiwa, Y.: Alkenone and alkenoic acid compositions of the membrane fractions of Emiliania huxleyi, Phytochemistry, 65, 1299-1307, https://doi.org/10.1016/j.phytochem.2004.03.015, 2004.

Schubert, C. J., Villanueva, J., Calvert, S. E., Cowie, G. L., von Rad, U., Schulz, H., Berner, U., and Erlenkeuser, H.: 
Stable phytoplankton community structure in the Arabian Sea over the past 200,000 years, Nature, 394, 563-566, https://doi.org/10.1038/29047, 1998.

Sharp, J.: Improved analysis for particulate organic carbon and nitrogen from seawater, Limnol. Oceanogr., 19, 984-989, https://doi.org/10.4319/lo.1974.19.6.0984, 1974.

Shemi, A., Schatz, D., Fredricks, H. F., Van Mooy, B. A. S., Porat, Z., and Vardi, A.: Phosphorus starvation induces membrane remodeling and recycling in Emiliania huxleyi, New Phytol., 211, 886-898, https://doi.org/10.1111/nph.13940, 2016.

Siebers, M., Doermann, P., and Hoelzl, G.: Membrane remodelling in phosphorus-deficient plants, in: Phosphorus Metabolism in Plants, edited by: Plaxton, W. C. and Lambers, H., Wiley-Blackwell, Chichester, UK, 237-263, https://doi.org/10.1002/9781118958841.ch9, 2015.

Sommer, U. and Lengfellner, K.: Climate change and the timing, magnitude, and composition of the phytoplankton spring bloom, Glob. Change Biol., 14, 1199-1208, https://doi.org/10.1111/j.1365-2486.2008.01571.x, 2008.

Sperfeld, E., Martin-Creuzburg, D., and Wacker, A.: Multiple resource limitation theory applied to herbivorous consumers: Liebig's minimum rule vs. interactive co-limitation, Ecol. Lett., 15, 142-150, https://doi.org/10.1111/j.1461-0248.2011.01719.x, 2012.

Thomsen, J., Gutowska, M. A., Saphörster, J., Heinemann, A., Trübenbach, K., Fietzke, J., Hiebenthal, C., Eisenhauer, A., Körtzinger, A., Wahl, M., and Melzner, F.: Calcifying invertebrates succeed in a naturally $\mathrm{CO}_{2}$-rich coastal habitat but are threatened by high levels of future acidification, Biogeosciences, 7, 3879-3891, https://doi.org/10.5194/bg-7-3879-2010, 2010.

Van Mooy, B. A. S., Fredricks, H. F., Pedler, B. E., Dyhrman, S. T., Karl, D. M., Koblizek, M., Lomas, M. W., Mincer, T. J., Moore, L. R., Moutin, T., Rappe, M. S., and Webb, E. A.: Phytoplankton in the ocean use non-phosphorus lipids in response to phosphorus scarcity, Nature, 458, 69-72, https://doi.org/10.1038/nature07659, 2009.

Vermont, A. I., Martinez, J. M., Waller, J. D., Gilg, I. C., Leavitt, A. H., Floge, S. A., Archer, S. D., Wilson, W. H., and Fields, D. M.: Virus infection of Emiliania huxleyi deters grazing by the copepod Acartia tonsa, J. Plankton Res., 38, 1194-1205, https://doi.org/10.1093/plankt/fbw064, 2016.

Véron, B., Billard, C., Dauguet, J. C., and Hartmann, M. A.: Sterol composition of Phaeodactylum tricornutum as influenced by growth temperature and light spectral quality, Lipids, 31, 989994, https://doi.org/10.1007/bf02522694, 1996.

Villanueva, L., Rijpstra, W. I. C., Schouten, S., and Damste, J. S. S.: Genetic biomarkers of the sterol-biosynthetic pathway in microalgae, Env. Microbiol. Rep., 6, 35-44, https://doi.org/10.1111/1758-2229.12106, 2014.

Volkman, J. K.: A review of sterol markers for marine and terrigenous organic matter, Org. Geochem., 9, 83-99, https://doi.org/10.1016/0146-6380(86)90089-6, 1986.

Volkman, J. K.: Sterols in microorganisms, Appl. Mirobiol. Biot., 60, 495-506, https://doi.org/10.1007/s00253-002-1172-8, 2003.

Volkman, J. K.: Sterols in microalgae, in: The Physiology of Microalgae, edited by: Borowitzka, M. A., Beardall, J., and Raven, J. A., Springer, Cham, Switzerland, 485-505, https://doi.org/10.1007/978-3-319-24945-2_19, 2016.
Volkman, J. K., Eglinton, G., and Corner, E.: Transformations of biolipids in the marine food web and in underlying bottom sediments, Colloques Internationaux du CNRS, 293, 185-197, 1980a.

Volkman, J. K., Eglinton, G., Corner, E., and Forsberg, T.: Long-chain alkenes and alkenones in the marine coccolithophorid Emiliania huxleyi, Phytochemistry, 19, 2619-2622, https://doi.org/10.1016/S0031-9422(00)83930-8, 1980b.

Volkman, J. K., Eglinton, G., Corner, E., and Sargent, J. R.: Novel unsaturated straight-chain $\mathrm{C}_{37}-\mathrm{C}_{39}$ methyl and ethyl ketones in marine sediments and a coccolithophore Emiliania huxleyi, Phys. Chem. Earth, 12, 219-227, https://doi.org/10.1016/00791946(79)90106-X, 1980c.

Volkman, J., Smith, D., Eglinton, G., Forsberg, T., and Corner, E.: Sterol and fatty acid composition of four marine Haptophycean algae, J. Mar. Biol. Assoc. UK, 61, 509-527, https://doi.org/10.1017/S0025315400047111, 1981.

Volkman, J. K., Barrett, S. M., Blackburn, S. I., Mansour, M. P., Sikes, E. L., and Gelin, F.: Microalgal biomarkers: A review of recent research developments, Org. Geochem., 29, 1163-1179, https://doi.org/10.1016/S0146-6380(98)00062-X, 1998.

von Elert, E., Martin-Creuzburg, D., and Le Coz, J. R.: Absence of sterols constrains carbon transfer between cyanobacteria and a freshwater herbivore (Daphnia galeata), P. Roy. Soc. B-Biol. Sci., 270, 1209-1214, https://doi.org/10.1098/rspb.2003.2357, 2003.

Winter, A., Henderiks, J., Beaufort, L., Rickaby, R. E. M., and Brown, C. W.: Poleward expansion of the coccolithophore Emiliania huxleyi, J. Plankton Res., 36, 316-325, https://doi.org/10.1093/plankt/fbt110, 2014.

Wolhowe, M. D., Prahl, F. G., Probert, I., and Maldonado, M.: Growth phase dependent hydrogen isotopic fractionation in alkenone-producing haptophytes, Biogeosciences, 6, 16811694, https://doi.org/10.5194/bg-6-1681-2009, 2009.

Wolhowe, M. D., Prahl, F. G., Langer, G., Oviedo, A. M., and Ziveri, P.: Alkenone $\delta \mathrm{D}$ as an ecological indicator: A culture and field study of physiologically-controlled chemical and hydrogenisotopic variation in $\mathrm{C}_{37}$ alkenones, Geochim. Cosmochim. Ac., 16, 166-182, https://doi.org/10.1016/j.gca.2015.04.034, 2015.

Wördenweber, R., Rokitta, S. D., Heidenreich, E., Corona, K., Kirschhöfer, F., Fahl, K., Klocke, J. L., Kottke, T., BrennerWeiss, G., Rost, B., Mussgnug, J. H., and Kruse, O.: Phosphorus and nitrogen starvation reveal life-cycle specific responses in the metabolome of Emiliania huxleyi (Haptophyta), Limnol. Oceanogr., 63, 203-226, https://doi.org/10.1002/lno.10624, 2018.

Xing, L., Zhao, M., Zhang, T., Yu, M., Duan, S., Zhang, R., Huh, C.-A., Liao, W.-H., and Feng, X.: Ecosystem responses to anthropogenic and natural forcing over the last 100 years in the coastal areas of the East China Sea, Holocene, 26, 669-677, https://doi.org/10.1177/0959683615618248, 2016.

Yamamoto, M., Shiraiwa, Y., and Inouye, I.: Physiological responses of lipids in Emiliania huxleyi and Gephyrocapsa oceanica (Haptophyceae) to growth status and their implications for alkenone paleothermometry, Org. Geochem., 31, 799-811, https://doi.org/10.1016/s0146-6380(00)00080-2, 2000. 
Zhao, M. X., Mercer, J. L., Eglinton, G., Higginson, M. J., and Huang, C.-Y.: Comparative molecular biomarker assessment of phytoplankton paleoproductivity for the last 160 kyr off Cap Blanc, NW Africa, Org. Geochem., 37, 72-97, https://doi.org/10.1016/j.orggeochem.2005.08.022, 2006.
Zimmerman, A. R. and Canuel, E. A.: Sediment geochemical records of eutrophication in the mesohaline Chesapeake Bay, Limnol. Oceanogr., 47, 1084-1093, https://doi.org/10.4319/lo.2002.47.4.1084, 2002. 